FINAL REPORT

\title{
Wetland Replacement Practices and Procedures for Indiana Highway Projects
}

FHWA/IN/JTRP-2002/18

by

James E. Alleman, Professor [Purdue University]

Steve M. Graves MS [Purdue University]

Project No: C-36-36EE

File No: 6-14-31

SPR-2205

\section{Joint Transportation Research Program Purdue University}

Prepared as Part of an Investigation Conducted by the Indiana Department of Transportation and the

Federal Highway Administration

U.S. Department of Transportation

The contents of this report reflect the views of the authors who are responsible for the facts and accuracy of the data presented herein. The contents do not necessarily reflect the official views of, or policies of any of the sponsors. Furthermore, this report does not constitute a standard, specification, or regulation.

\section{School of Civil Engineering \\ Purdue University \\ West Lafayette, Indiana 47907}

June 2002 


\section{TECHNICAL Summary}

INDOT Research

Technology Transfer and Project Implementation Information

TRB Subject Code: 17-2 Ecological Systems

Publication No.: FHWA/IN/JTRP-2002/18, SPR-2205

June 2002

Final Report

\section{Wetland Replacement Practices and Procedures for Indiana Highway Projects}

\section{Introduction}

This project originated from the need to determine what has led to the loss of wetlands within the state of Indiana. In particular, INDOT has been blamed for contributing to wetlands destruction within the state in relation to their historical involvement with Highway construction. This accusation assumes, rightly or wrongly, that the construction of state and federal roads carried out by INDOT has adversely affected wetlands on both a quantitative and qualitative basis. Whether the accusation of a negative impact quantitatively is properly placed is the purpose of this research.

\begin{abstract}
Aspects of wetlands that were examined include the extent of lands that were potentially historic wetlands, the relationship between these and the wetlands that currently exist within the state of Indiana, the relationship between road proximity and the prevalence of wetlands, and the relationship between farming intensity and wetlands and forest cover and wetlands. This research does not seek to determine any qualitative effects of road construction and proximity of roads on wetlands.
\end{abstract}

\section{Findings}

This research was carried out primarily with the use of geographic information systems (GIS). GIS are digitized computer mapping systems that allow precisely scaled digitized maps to be linked to data/spreadsheets about the components (shapes, lines, points) with the maps. Maps using the same scale, datum and data storage format can be brought seamlessly together into a project. Maps can be layers and maps and data can be edited.

For this project a commercial program was used, ArcView GIS 3.2, a Windows-based GIS system developed by Environmental Systems Research Institute, Inc. (ESRI). Digital and nondigital data available on the web was used from several arenas including the USDA National Forest Service Inventory Analysis (FIA), the U.S. Dept. of Interior U.S. Fish and Wildlife Service National Wetlands Inventory (NWI), the U.S. Dept. of Agriculture National Resource Conservation Service (NRCS) soils data, the U.S.
Dept. of Agriculture 1997 Census of Agriculture, and Purdue University.

The results obtained with this study demonstrated that while wetlands prevalence (i.e., percent wetlands land area relative to total land area) decreased slightly in land areas close to state and federal roads (i.e., within the adjacent 500 to $1,000 \mathrm{ft}$. land reach), this change did not explain the dramatic decrease (in excess of $80 \%$ ) in wetlands that has occurred in Indiana. In fact, hydric soil prevalence, a common indicator parameter for wetland areas, decreased only to a slight extent in land areas close to federal and state roads.

Since soil data are not expected to change much over time, the latter fact (i.e., the nominal decrease in hydric soil lands immediately adjacent to highways) indicates that the slight decrease in wetlands near state and federal roads is not due to adverse effects by road construction itself. Instead, this decrease may be due to roads being 
constructed in areas and paths intended to avoid wetlands and hydric soils, thus lowering construction time and costs.

While the data developed in this project do not clearly indicated whether state and federal road construction has had an obvious quantifiable negative impact on wetlands, these data do not indicate that if there was an impact, it was a very small impact in comparison to the dramatic decline in wetlands that has been estimated to have occurred within the state of Indiana. This decline could be due to many factors and research in this project has shown a correlation between wetlands loss as represented by the wetlands to hydric soil ratio and farming intensity and an opposite correlation between wetland loss and forest cover. The greater the farming intensity within a county, the greater was the estimated loss of wetlands. Also, a greater the area of forest cover within a county correlated with a lower estimated wetland loss.

\title{
Implementation
}

The topic of relative wetlands loss in the state of Indiana, and particularly the correlation between wetlands loss and land use in a general context, is an area in which more research could be performed. Two other factors that have not been examined in this project are the effect of county roads upon wetlands and the effect of urban sprawl upon wetlands.

These latter two factors likely played significant roles in wetland destruction. A problem lies in separating the effects on wetlands of agriculture, urban sprawl, state and federal roads, and county roads from each other. All of these developments occurred simultaneously and often overlap each spatially.

The lack of a consistently strong correlation of wetlands lying on hydric soils is also troubling. One of the key scientific foundations for this project was the part of the definition of a wetland which requires it to be characterized by hydric soils. This correlation was considered to be the only way possible to gauge an estimate of historic wetlands.

However, the discrepancy between the wetlands definition and the fact that many NWI wetlands, which are based upon the wetland hydrology part of the wetland definition do not lie within SSURGO hydric soils, introduces a certain amount of error in this process. Conversely, NWI data are the best wetlands data available and the USDA SSURGO soils data are the best soils data available. This correlation between wetland presence and hydric soil characterization should, therefore, be given further research in conjunction with the future implementation of this project's current research findings.

\section{Contacts}

For more information:

\author{
Indiana Department of Transportation \\ Division of Research \\ 1205 Montgomery Street \\ P.O. Box 2279 \\ West Lafayette, IN 47906 \\ Phone: (765) 463-1521 \\ Fax: (765) 497-1665 \\ Purdue University \\ Joint Transportation Research Program \\ School of Civil Engineering \\ West Lafayette, IN 47907-1284 \\ Phone: (765) 494-9310 \\ Fax: (765) 496-7996 \\ http://www.purdue.edu/jtrp
}




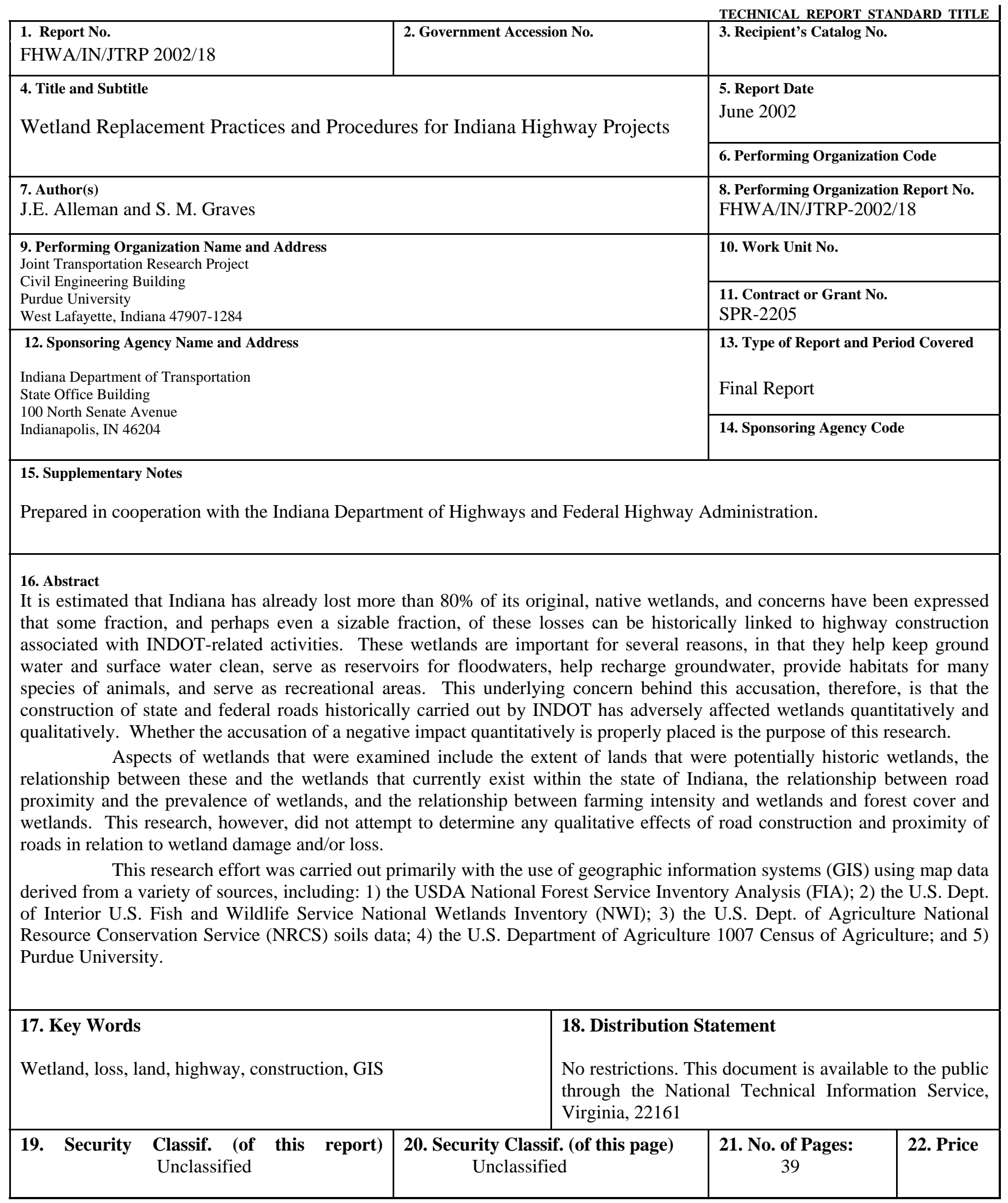

Form DOT F 1700.7 (8-69) 


\section{ACKNOWLEDGMENTS}

The authors would like to acknowledge the following individuals....

- $\quad$ Barry Partridge, INDOT, Chief, INDOT Division of Research

- David Ward, INDOT Section Manager,

[INDOT Applied and Environmental Research, Electrical Engineering and Technical Support]

...for their technical assistance, professional insight, and financial support 


\section{TABLE OF CONTENTS}

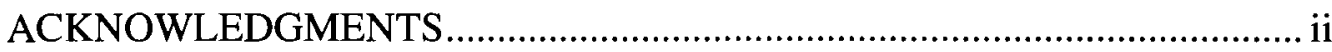

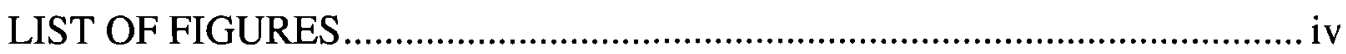

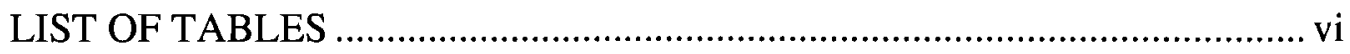

ACRONYMS AND ABBREVIATIONS .................................................. vii

IMPLEMENTATION REPORT ................................................................. viii

EXECUTIVE SUMMARY ....................................................................

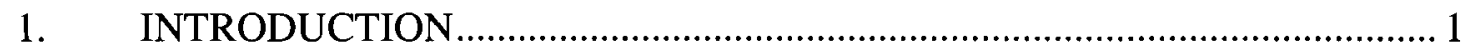

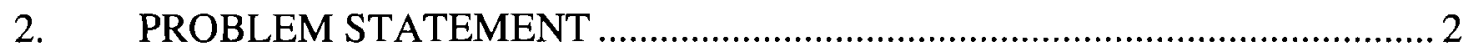

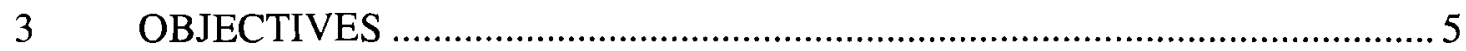

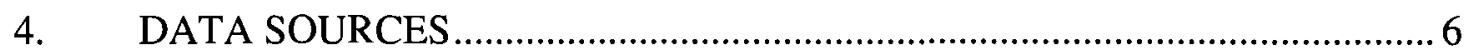

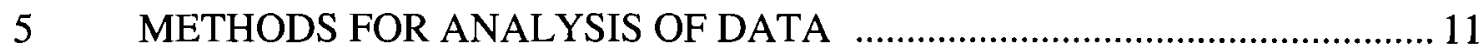

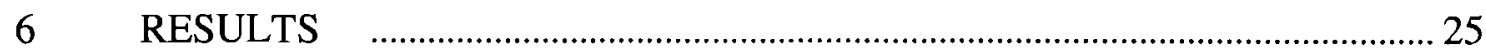

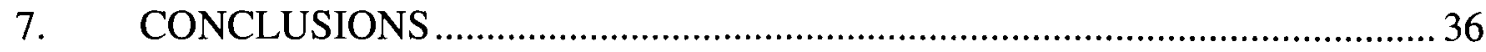

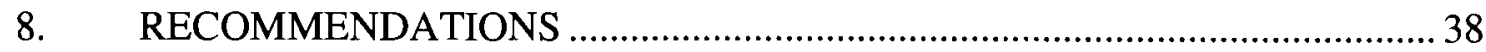

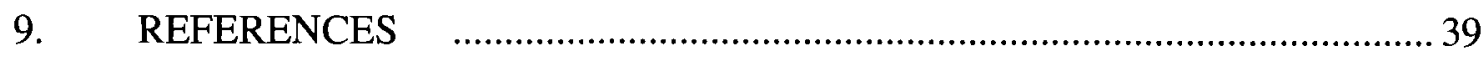




\section{LIST OF FIGURES}

Number Title

Page

$1 \quad$ NWI progress on a national wetlands mapping project 7

2 SSURGO data available online 9

3 Indiana rivers and streams shapefile with Tippecanoe

County boundary superimposed. 12

4 Indiana roads shapefile with Tippecanoe County boundary superimposed ........ 12

5 Danville wetlands shapefile with Tippecanoe County border superimposed ..... 13

6 Tippecanoe County rivers and streams shapefile ....................................... 14

$7 \quad$ Tippecanoe County roads shapefile …....................................................... 14

$8 \quad$ Tippecanoe County wetlands shapefile..................................................... 14

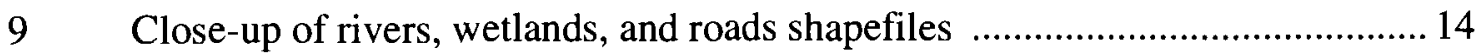

10 Query process for selection of SSURGO soils that are hydric ....................... 15

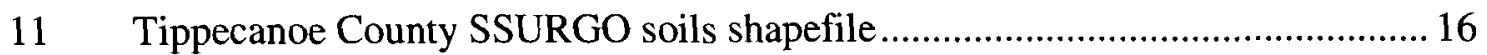

12 Tippecanoe County hydric soils shapefile ................................................ 16

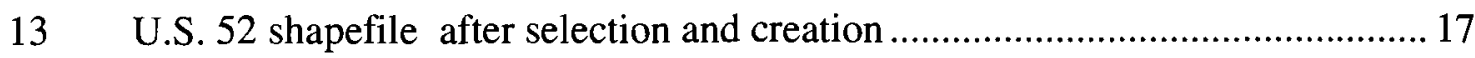
from the roads shapefile.

14 State and federal roads shapefile with the roads shapefile ............................... 17

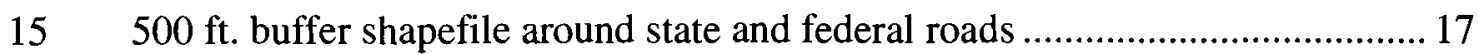

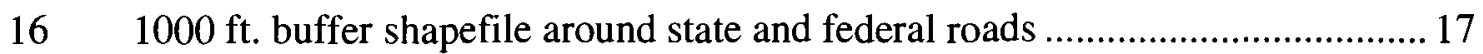

17 Wetlands within 1000 feet of state and federal roads ..................................... 18

18 Hydric soils within 1000 feet of state and federal roads ................................. 18

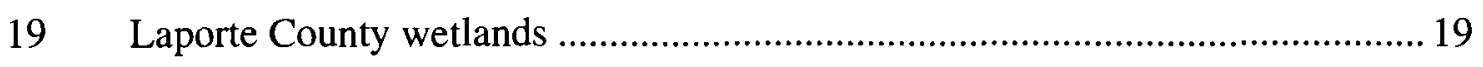

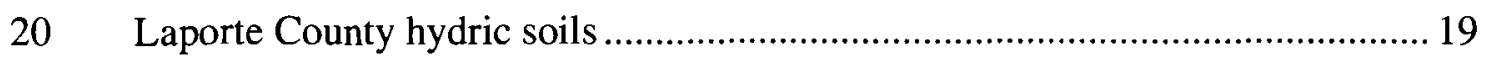

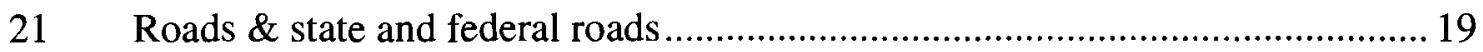


22 Close up of the city of Laporte with wetlands layered above hydric soils with roads

231000 foot wetlands for Laporte County 19

241000 foot hydric soils for Laporte County 19

25 Wetland shapefiles downloaded for Buena Vista County. 20 and brought into ArcView

26 Wetland themes merged into a single wetland shapefile . 20

27 Clipped wetlands shapefile for Buena Vista County layered above the merged wetlands shapefile

28 Wetlands shapefile layered above the Buena Vista County shapefile

29 SSURGO shapefiles downloaded for Buena Vista County 22

30 SSURGO shapefiles merged into a single SSURGO shapefile .22

31 Clipped SSURGO shapefile for Buena Vista County, IA ............................... 23

32 Hydric soils shapefile for Buena Vista County, IA ........................................2 23

33 Wetlands of Wright County Minnesota .................................................... 24

34 Hydric soils of Wright County Minnesota .................................................... 24

35 Graph of wetlands and their prevalence near and away from roads ..................2 27

36 Graph of hydric soils and their prevalence near and away from roads .............. 28

$38 \quad$ Relationship between wetland loss and forest cover...................................... 32

39 Southeastern Tippecanoe County wetlands...................................................... 34

$40 \quad$ Southeastern Tippecanoe County hydric soils ............................................ 34 


\section{LIST OF TABLES}

Number

1 Results from Indiana counties concerning the prevalence 25 of wetlands near state and federal roads

2 Results from Indiana counties concerning the prevalence 25 of hydric soils near state and federal roads

3 Ratio of current wetlands to hydric soils, an indicator. of potential historic wetlands

4 Results from counties around the eastern U.S. concerning the relationship between farming intensity and wetlands prevalence

5 Results from counties around the eastern U.S. concerning the relationship ....... 31 between woodland prevalence and wetlands prevalence

6 Percent of wetlands lying within hydric soils for several counties .33 


$\begin{array}{ll}\text { CAAGIS } & \text { Center for Advanced Applications in GIS } \\ \text { EPA } & \text { US Environmental Protection Agency } \\ \text { ESRI } & \text { Environmental Systems Research Institute } \\ \text { FIA } & \text { Forest Inventory Analysis (USDA) } \\ \text { FWS } & \text { US Fish and Wildlife Service } \\ \text { GIS } & \text { Geographical information system } \\ \text { INDOT } & \text { Indiana Department of Transportation } \\ \text { NAD } & \text { North American Datum } \\ \text { NRCS } & \text { National Resource Conservation Service } \\ \text { NWI } & \text { National Wetlands Inventory (US_Fish and Wildlife Service) } \\ \text { SSURGO } & \text { Soil Survey Geographic Database } \\ \text { USGS } & \text { US Geological Survey } \\ \text { USDA } & \text { US Department of Agriculture }\end{array}$




\section{IMPLEMENTATION REPORT}

The topic of relative wetlands loss in the State of Indiana, and particularly the correlation between wetlands loss and land use in a general context, is an area in which more research certainly could, and should, be performed in conjunction with the future implementation of this existing project. Two such important factors that have not been examined in this project are the effect of county roads upon wetlands and the effect of urban sprawl upon wetlands.

These latter two factors likely played significant roles in wetlands destruction. A problem lies in separating the effects on wetlands of agriculture, urban sprawl, state and federal roads, and county roads from each other. All of these developments have occurred simultaneously and often overlap each other spatially.

The lack of a consistently strong correlation of wetlands lying on hydric soils is also troubling. One of the key scientific foundations for this project was the part of the definition of a wetland which requires it to be characterized by hydric soils. This correlation was considered to be the only way possible to gauge an estimate of historic wetlands.

However, the discrepency between the wetlands definition and the fact that many NWI wetlands, which are based upon the wetland hydrology part of the wetland definition, do not lie within SSURGO hydric soils introduces a certain amount of error in this process. Conversely, NWI data is the best wetlands data available and the USDA SSURGO soils data is the best soils data available. This correlation between wetland presence and hydric soil characterization should, therefore, be given further research relative to the future implementation of this project's current research findings. 


\section{EXECUTIVE SUMMARY}

In Indiana, it is reported that the majority of original wetland area (approximately 85\%) has been lost. As defined by the Indiana Wetlands Conservation Plan (DNR 1996), wetlands are qualified on the following basis:

"Wetlands are lands transitional between terrestrial and aquatic systems where the water table is usually at or near the surface or the land is covered by shallow water."

These wetlands are important for several reasons, in that they help keep ground water and surface water clean, serve as reservoirs for floodwaters, help recharge groundwater, provide habitats for many species of animals, and serve as recreational areas. Indeed, wetlands serve many important functions, both in human benefits such as maintaining water quality and flood control and environmental benefits such as providing a habitat for endangered plants and animals. As a result, on a national level it has been recognized that a critical need exists to retain native wetlands areas whenever possible... and to replace wetlands lost or damaged with suitable new man-made wetlands areas.

Unfortunately, though, concerns have been expressed that some fraction, and perhaps even a sizable fraction, of these wetlands losses (i.e., $~ 85 \%$ ) can be linked to highway construction associated with INDOT-related activities. While these lands could well have been drained and/or filled mostly for agriculture production, it is also possible that some degree of loss has also resulted from highway construction.

The underlying concern behind the accusation regarding INDOT's adverse historical impact on wetlands, therefore, is that the construction of state and federal roads carried out by INDOT might have negatively affected wetlands on both a quantitative and qualitative basis. Whether the accusation of a negative impact quantitatively is properly placed, or not, is the purpose of this research.

Aspects of wetlands that were examined include the extent of lands that were potentially historic wetlands, the relationship between these and the wetlands that currently exist within the state of Indiana, the relationship between road proximity and the prevalence of wetlands, and the relationship between farming intensity and wetlands 
and forest cover and wetlands. This research, however, did not attempt to determine any qualitative effects of road construction and proximity of roads in relation to wetland damage and/or loss.

This research effort was carried out primarily with the use of geographic information systems (GIS) using map data derived from a variety of sources, including: 1) the USDA National Forest Service Inventory Analysis (FIA), 2) the U.S. Dept. of Interior U.S. Fish and Wildlife Service National Wetlands Inventory (NWI), 3) the U.S. Dept. of Agriculture National Resource Conservation Service (NRCS) soils data, 4) the U.S. Dept. of Agriculture 1997 Census of Agriculture, and 5) Purdue University.

As mandated by Presidential Executive Order, the Indiana Department of Transportation (INDOT) is now required to replace wetlands which are removed or impacted during highway construction on an acre-for-acre basis such that there is no net loss of surficial wetland area. Existing wetlands negatively harmed during these construction activities will either have to be totally replaced (e.g., creating entirely new sites) or enlarged (e.g., expanding an existing site). In all cases, the ratio of new wetland area to impacted wetland area must be greater than $2: 1$. For certain critical wetland areas, the replacement ratio may be as large as $4: 1$. The goal in either case is to create a selfsustaining habitat for aquatic plants and animals which provides the same function as the impacted wetland.

Currently, INDOT is involved in 50 to 60 wetland delineations/yr., which result in about 10 wetland mitigations/yr. The primary obstacle currently faced by INDOT with regard to wetlands is a lack of wetlands inventory data for Indiana. Simply stated, INDOT has experienced difficulty dealing with wetlands because it does not have accurate information on wetland locations, areas, and types. Such information is needed to minimize the impact of new construction and, where necessary, to optimize the mitigation actions for impacted wetlands.

The current available data sources (USGS quadrangle maps, aerial photos, U. S. Fish and Wildlife National Wetlands Inventory maps) are typically out of date or unconfirmed, and as a result are reliable only for larger wetlands (greater than 20 acres). Thus, the process of highway planning, design, and construction may be delayed until 
time-consuming field reconnaissance is completed. INDOT is one of many organizations that are affected by the lack of reliable wetlands inventory information.

For this reason, the Indiana Task Force on Wetlands has been created and includes members from INDOT (Steve Cecil), Indiana Department of Environmental Management (IDEM), the Indiana Department of Natural Resources (IDNR), industry, conservation groups, and community groups. The Indiana Task Force on Wetlands has identified the need for updated wetland inventory information as a top priority. Likewise, one of the objectives of the Indiana Wetlands Conservation Plan (p. 44) is to "have an inventory system capable of quantitatively identifying and monitoring Indiana's wetlands in place by May 1998".

In some areas of the U. S., wetland replacement is practiced on an in-kind basis in which the vegetation of the replacement area must be the same as that lost to a project. This approach is straightforward, but it assumes that wetland functions correlate with vegetation structure, which may not in actuality be the case. In-kind replacement also may not take into consideration the importance of site location in replicating the functions of the wetland. Thus, the current trend is away from in-kind vegetation replacement and towards the concept of wetland functional replacement. This involves a more detailed consideration of site selection and design, the type and condition of underlying soils, and surface water and groundwater quality at these sites (FHWA 1990).

Public concern regarding the preservation of remaining wetlands has resulted in the enactment of federal, state, and local laws. Examples of important federal mandates include sections of the Clean Water Act, the Coastal Zone Management Act, and the National Environmental Policy Act. In addition, a wide range of policies and regulations have been enacted at the state level. Wetland laws, regulations, and policies vary from state to state. Many have specific mitigation policies relating to wetland replacement, including the required replacement ratio, the location of the mitigation site (off-site vs. on-site), as well as the type of mitigation allowed (in-kind vs. out-of-kind). 


\section{INTRODUCTION}

This project originated from the need to determine what has led to the loss of wetlands within the state of Indiana. In particular INDOT, the Indiana Department of Transportation, is an organization that has been blamed for some of the wetlands destruction within the state. This accusation assumes that the construction of state and federal roads carried out by INDOT has adversely affected wetlands quantitatively and qualitatively. Whether the accusation of a negative impact quantitatively is properly placed or not is the purpose of this research. Aspects of wetlands that were examined include the extent of lands that were potentially historic wetlands, the relationship between these and the wetlands that currently exist within the state of Indiana, the relationship between road proximity and the prevalence of wetlands, and the relationship between farming intensity and wetlands and forest cover and wetlands. This research does not seek to determine any qualitative effects of road construction and proximity of roads on wetlands.

This research was carried out primarily with the use of geographic information systems, GIS. GIS are digitized computer mapping systems that allow precisely scaled digitized maps to be linked to data/spreadsheets about the components (shapes, lines, points) within the maps. Maps using the same scale, datum and data storage format can be brought seamlessly together into a project. Maps can be layered and maps and data can be edited. For this project a commercial program was used, ArcView GIS 3.2, a windows based GIS system developed by ESRI, Environmental Systems Research Institute, Inc. Digital and non-digital data available on the web was used from several arenas including the USDA National Forest Service Inventory Analysis (FIA), the U.S. Dept. of Interior U.S. Fish and Wildlife Service National Wetlands Inventory (NWI), the U.S. Dept. of Agriculture National Resource Conservation Service (NRCS) soils data, the U.S. Dept. of Agriculture 1997 Census of Agriculture, and Purdue University. 


\section{PROBLEM STATEMENT}

It is estimated that Indiana has already lost about $87 \%$ of its original wetlands. These wetlands are important for several reasons, they help keep ground water and surface water clean, serve as resevoirs for floodwaters, help recharge groundwater, provide habitats for many species of animals, and serve as recreational areas (Miller and MacGowan). Originally the idea behind this project was to develop an historical wetlands map of a couple of Indiana counties, including Tippecanoe county, in a time period approximately 50 years ago with the use of aerial photographs from the 1940's or 1950's and a 1940's Map of the Soil Associations in Indiana put out by the Soil Conservation Service. This historical wetlands map would then be used in comparison against a current wetlands map and a map of state and federal roads. Several difficulties occurred with this strategy.

First the 'Map of the Soil Associations in Indiana' had no classification system to precisely identify wetlands. This is partially due to wetland preservation and identification not becoming important in this country until the 1970's and later. The best approximation using the Soil Association map was several classifications identified by a common theme, muck, but this classification was never determined to have a direct correlation to the present definition and classification scheme for wetlands. Another problem stemmed from the Soil Association map not being digitized and with the level of detail existing in this map the process to digitize that map would be extremely difficult and time consuming, far beyond the scope for this project.

A second problem stemmed from the aerial photographs. It was believed that these might be of some use in identifying wetlands as they existed 50 years ago but examination of them led to the conclusion that is was not possible to distinguish many wetlands from forests. "...the most common wetland types in Indiana are forested wetlands and small temporarily flooded wetlands in farmed fields." (Miller and MacGowan). So a new approach was needed. One note of interest that the aerial photographs did reveal was that many of the state and federal roads in Tippecanoe County were already constructed by the 40 's and 50's. Thus the value of these aerial 
photographs is further limited since they would not indicate wetland extent before state and federal road development.

The current technical and federal government definition of wetlands is “....areas that have a predominance of hydric soils and that are inundated or saturated by surface or ground water at a frequency and duration sufficient to support a prevalence of hydrophytic vegetation typically adapted for life in saturated soil conditions." (NRCS Distribution of Wetlands).

"Wetlands have three essential characteristics: hydric soils, hydrophytic vegetation, and wetland hydrology. Hydrophytic vegetation is plant life growing in water or in soils that are periodically deficient in oxygen as a result of saturation of the soil with water, such as cattails, sedges, and willows. Wetland hydrology refers to periodic inundation (flooding or ponding) or saturation to the soil surface, usually for a week or more. Hydric soils are those that are saturated, flooded, or ponded long enough during the growing season to develop anaerobic conditions in the upper part." (Franzmeier and Kladivko)

This definition of hydric soils is confirmed on the USDA - NRCS web page entitled Hydric Soils of the United States located at the following Web site location:

\section{http://www.statlab/iastate/edu/soils/hydric/intro.htm.}

The Army Corps of Engineers requires all three parts of the definitions of a wetland be used in the determination and delineation of wetlands. The first part of the wetland definition, hydrophytic vegetation, while a useful current delineation and classification tool, posed a problem with acquiring historical vegetation data. No digitized historical vegetation data exists that could be found. Nor was any digitized data on historical wetlands hydrology found. Interestingly the current National Wetlands Inventory uses wetland hydrology as its primary tool for identifying current wetlands (Santos).

Hydric soils were determined as the best tool for mapping historical wetlands. As it turns out hydric soils are readily obtained from USDA SSURGO digitized data that is available for download from the web. Using the USDA digital soils map then the best initial estimate of an historical wetlands map would be to select all the hydric soils, one part of the federal definition of a wetland (Harbor). Approximately $26 \%$ of Indiana soils are hydric (Franzmeier and Kladivko). 
"Before any drainage systems were installed, practically all of these soils would have qualified as wetlands by the current definition. Recent observations in undrained areas, however, show that hydrophytic vegetation does not extend quite as high in the landscape as do hydric soils. Thus at the time of European settlement, about $25 \%$ of Indiana would have qualified as wetlands according to the current technical definition." (Franzmeier and Kladivko).

While not a precise gauge of historical wetlands, hydric soils was the best method found for approximating the wetlands that existed prior to settlement of and development of the lands in Indiana. Use of hydric soils for this purpose is consistent with the definition of wetlands.

Using hydric soils is not a good measure of wetlands in the 1940's because many wetlands had already been drained by that time as Indiana had been settled for over 100 years. Also, as has been pointed out previously, state and federal road development had already been active prior to the 1940's. Hydric soils are a better measure of the effect of road development on wetlands as they existed prior to any road or agricultural development, which significantly predates the 1940's. There are many factors that could explain the loss of wetlands besides state and federal road construction, such as county road construction, urban sprawl, deforestation, and agricultural development. Since all of these factors occurred concurrently it is difficult to separate them from one another but this project has attempted to develop some correlation between state and federal road construction, agricultural prevalence, and the extent of forest cover to the decline in wetlands. 


\section{OBJECTIVES}

The following list summarizes the primary objectives for this research effort:

- to develop a methodology for accurately quantifying the location and area of existing wetlands in selected state regions using current spatial imaging resources (e.g., GIS analysis of National Wetlands Inventory maps, etc.),

- to devise a system for determining a historical correlation between highway location and current historical wetland area shifts,

- to test the accuracy of the methodology and system by actual field verification of selected wetland sites in two specific counties, and

- To investigate and characterize the accusation regarding INDOT's adverse historical impact on wetlands, whereby the construction of state and federal roads carried out by INDOT might have negatively affected wetlands on both a quantitative and qualitative basis. Whether the accusation of a negative impact quantitatively is properly placed, or not, is the purpose of this research. 


\section{DATA SOURCES}

The digital wetlands data used in this project originated from the National Wetlands Inventory, NWI, whose web site is located at http://www.nwi.fws.gov/. NWI, a division of the U.S. Fish and Wildlife Service, FWS, lies within the U.S. Department of the Interior, and "... produces information on the characteristics, extent, and status of the Nation's wetlands and deepwater habitats." (NWI homepage.) In 1986 the U.S. Congress passed the Emergency Wetland Resources Act of 1986 which instructed the Fish and Wildlife Service to develop maps and a digital database of the wetlands of the United States. To date the NWI has mapped $89 \%$ and digitized $39 \%$ of the wetlands of the lower 48 states. "This information is used by Federal, State, and local agencies, academic institutions, the U.S. Congress, and the private sector." (NWI Overview.)

"The source material used to produce the National Wetlands Inventory (NWI) digital data for these maps was prepared primarily by stereoscopic analysis of high altitude photographs based on vegetation, visible hydrology, and geography in accordance with the Classification of Wetlands and Deepwater Habitats of the United States." (Santos). NWI wetlands maps for Indiana were developed using “...color infrared photography from the early to mid 1980's, and some field verification. Soil surveys were used as collateral data only." (Santos). Wetlands that have been mapped and those that have been digitized and are available for downloading are presented on the following map located at http://www.ftw.nrcs.usda.gov/jpg/archived.jpg. 


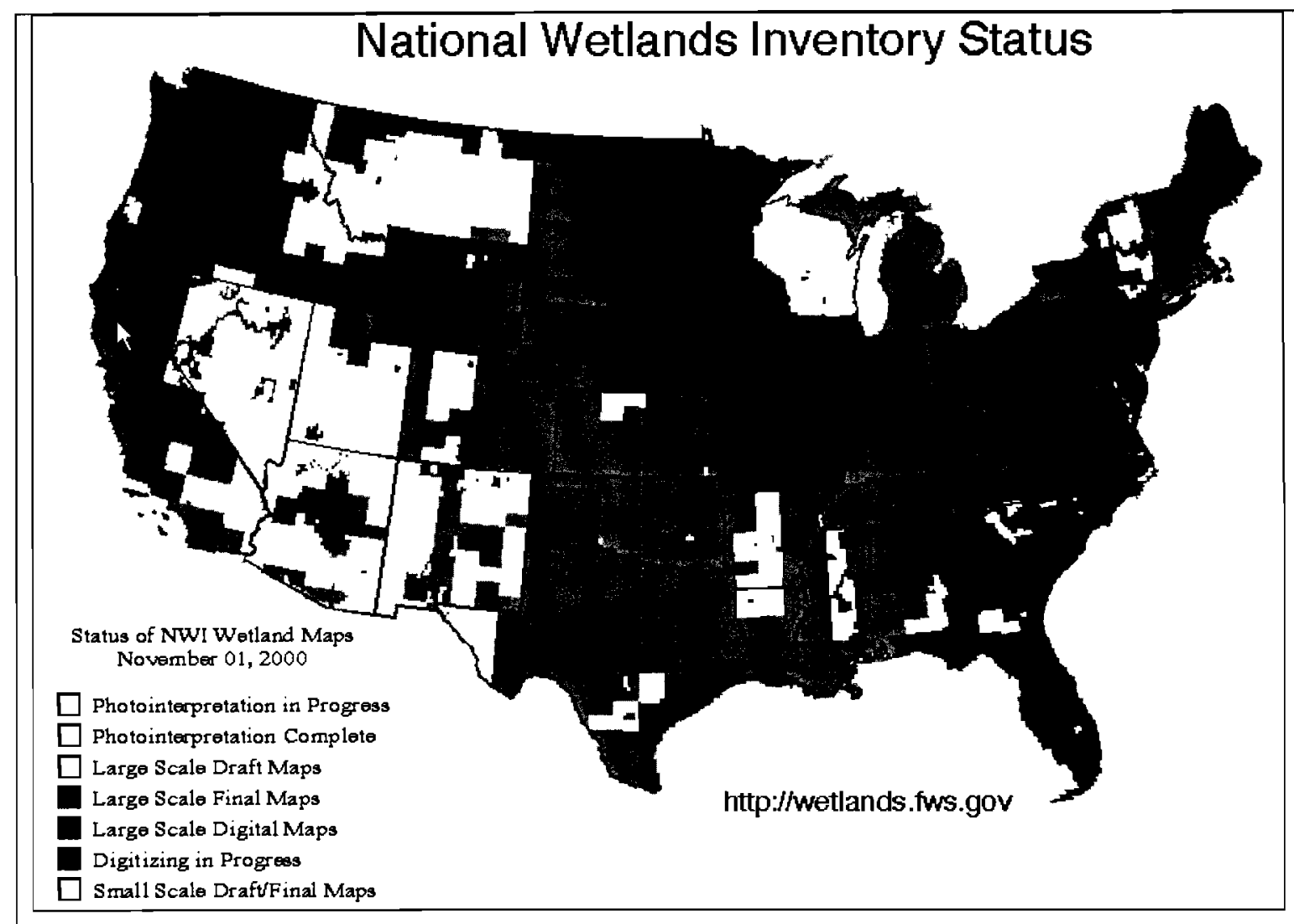

Figure 1: NWI progress on a national wetlands mapping project.

To download NWI data these series of sites were used. From the NWI site at http://www.nwi.fws.gov/ a link titled Wetlands Interactive Mapper was used. This links to http://wetlands.fws.gov/mapper tool.htm where the user must choose data from either the eastern half or the western half of the nation. Only states east of Kansas City were used for this project. Thus the eastern half of the nation is selected from the St. Petersburg, FL link. This web site, http://wetlands2.nwi.fws.gov/nwi mapplet/, brings up a form where a county name must be input. Upon selecting the proper county state combination (there are often several counties with the same name but in different states) the submit button is depressed and a wetlands map of that county and surrounding areas is accessed. County, wetland, road, and river data can be downloaded from this site in two file formats. The easiest to use is the ESRI format files which can brought directly into ArcView GIS as a theme or shapefile. But first these downloaded files, which are zip files, must be unzipped. Files throughout this project were unzipped using WinZip 7.0 . 
Digital soil data was acquired from the National Resources Conservation Service, NRCS, which is an agency within the U.S. Department of Agriculture, USDA. The need for the NRCS, originally the Soil Conservation Service, grew out of the Dust Bowl era of the 1930's when soil erosion suddenly became a serious concern. The mission of the NRCS is to facilitate a partnership between federal agencies and local communities to encourage conservation of national resources such as land, soil, air, water, plants and animals. The NRCS encourages responsible stewardship of these resources by private landowners, such as farmers and ranchers, and provides technical assistance to these landowners. (NRCS at a Glance).

The NRCS heads the National Cooperative Soil Survey, NCSS, which maintains three soil geographic databases "...for collecting, storing, maintaining, and distributing soil survey information for privately owned lands in the United States." (NRCS SSURGO Data Users Guide). These three databases are the Soil Survey Geographic database, SSURGO, the State Soil Geographic database, STATSGO, and the National Soil Geographic database, NATSGO. NATSGO data is intended for use in national resource planning, while STATSGO data is intended for state resource planning. SSURGO data provides the most detailed information and was designed for local planning such as counties, townships, farmers, ranchers, and other landowners. SSURGO data was chosen for this project due to its level of detail and its identification of soils as being hydric or non-hydric. SSURGO is the only soil database with a sufficient level of detail for use with this project.

The counties in the US where digital SSURGO data is available for downloading is presented in the following map located at http://www.ftw.nrcs.usda.gov/jpg/archived.jpg. 


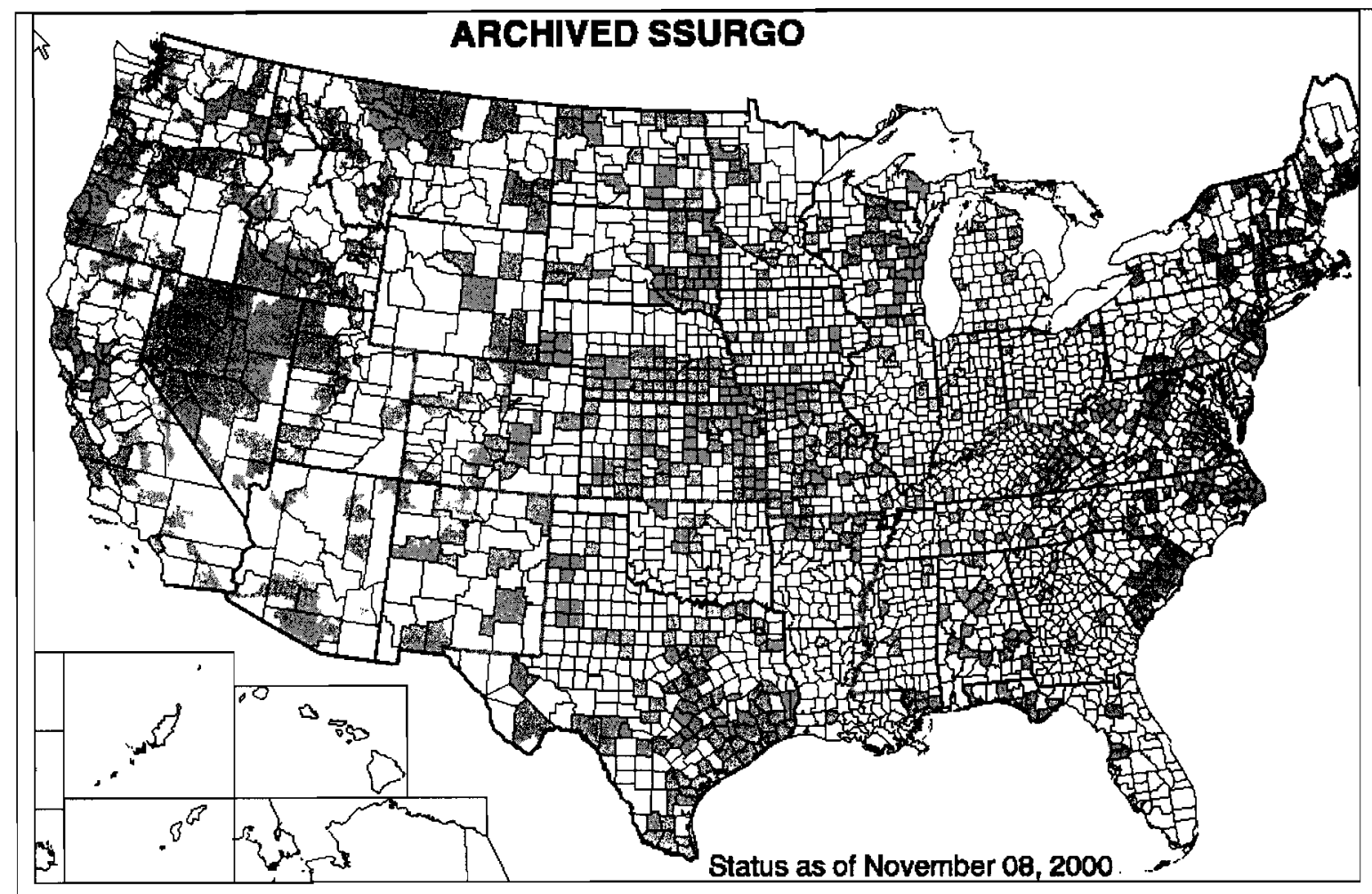

Figure 2: SSURGO data available online.

SSURGO digitized data is available from these web pages. http://www.nrcs.usda.gov/TechRes.html is the technical resources page for the NRCS. From here soils data is accessed via the "Soils Data" link, http://www.statlab.iastate.edu/soils/nsdaf/ which is a web page that links to various different soil formats. One of these is SSURGO data, accessed via the "SSURGO" link http://www.ftw.nrcs.usda.gov/ssur_data.html. On this page several links are available, the detailed PDF format 'User's Guide' description of SSURGO data, the national archived county map (pictured above), and a link to download SSURGO Data. At this point an account with NRCS is required, which is free, and then SSURGO data is available for download by county. There are close to 1000 counties currently in the database, with more being added all the time, which is arranged alphabetically by state abbreviation then county.

A convenient source of data to download for the state of Indiana is through the Center for Advanced Applications in GIS, CAAGIS, of Purdue University located at this web site, http://danpatch.ecn.purdue.edu/ caagis/ftp/gisdata/data.html. Here SSURGO data can be downloaded for six of the eleven counties in Indiana that have had their soils 
data digitized by the NRCS. Other useful data available for download at this site include roads, railroads, rivers and streams, county boundaries, and others. Wetlands data acquired from NWI can also be downloaded from this site.

Early on in this project the advantage of using this site is that all downloadable data can be acquired in NAD 83 format. All CAAGIS data is available in both NAD 83 and NAD 27, except for wetlands, which like the NWI download site, is only available in NAD 83. SSURGO data available from the NRCS download site was found early in this project to be in NAD 27, but more recent downloads have resulted in files in NAD 83 format. NAD stands for North American Datum and is a reference against which the maps are constructed. NAD 27 is the old standard developed in 1927. NAD 83 is the current U.S. standard developed in 1983 and is GPS compatible. For Indiana, if NAD 27 and NAD 83 soils data for the same county are brought together into a map and layered on top of each other, an approximate $100 \mathrm{~m}$ north south shift results between the two data sets. This separation of the data means that map layers are not precisely placed on top of one another and limits the level of editing and calculations that can be performed on the maps.

There are methods to convert a data file from one datum to another datum, but the most reliable method is in a program called ArcInfo, which was not learned for this project. The newest version of ArcView contains a tool for this conversion but it is reported to be unreliable and was also not learned for this project.

Another source of data used in this project was the USDA 1997 Census of Agriculture located at http://www.nass.usda.gov/census/census $97 /$ volume1/vol1pubs.htm. At this site a wealth of statistical data is available on state and county agriculture. For this project data gathered included county area, percent of county that is farmland, and farm acreage within the county.

Also used was the USDA National Forest Service, Forest Inventory and Analysis (FIA), located at http://fia.fs.fed.us. From here the state where data is desired is selected and the FIA table generator is used to pull up the information desired. For this project the data gathered was the forest cover for each county analyzed. 


\section{METHODS FOR ANALYSIS OF DATA}

Two methods were used to develop useful maps and data for this project. The first entailed using CAAGIS data to develop detailed GIS maps of several counties in Indiana. Each final map included the county itself and within the county state and federal roads, railroads, all county roads, rivers and streams, total hydric soils, hydric soils within 1000 ' of state and federal roads, hydric soils within 500 ' of state and federal roads, total wetlands, wetlands within 1000' of state and federal roads, wetlands within 500 ' of state and federal roads, and areas common to both hydric soils and wetlands. This method was used primarily to examine the relationship between loss of wetlands and the proximity to state and federal roads. Unfortunately much of this work had to be repeated using data from NWI and NRCS due to some inconsistencies of the CAAGIS data.

The second method employed entailed using NWI data, NRCS data, FIA data, and USDA Census data to develop GIS maps of other counties around the nation. Each final map included the county itself, total wetlands, total hydric soils, and the areas common to both wetlands and hydric soils. This data was used to examine the relationship between current and estimated historical wetlands to the level of agricultural activity within the county and the forest cover of each county. This method was initially used to look at only counties outside of Indiana, but the later revised versions of the Indiana counties examined in detail were constructed using this same method. Thus this second method proved to be the method of choice mainly due to the format of the NRCS and NWI data being more reliable, i.e. in a consistent NAD format. In these revisions CAAGIS roads and streams data was still used, but county boundaries, wetlands, and hydric soil data was acquired elsewhere. A detailed description of the steps involved in performing both methods, creating both types of GIS maps, follows.

The path for constructing detailed maps of each Indiana county was the same except for the data sets used. The steps in developing the Tippecanoe County map data will be presented. First the data must be downloaded from the CAAGIS web site, http://danpatch.ecn.purdue.edu/ caagis/ftp/gisdata/data.html. Files that were downloaded included counties, roads, railroads, rivers and streams, wetlands from the Danville section 
of the Indiana Map since Tippecanoe county is located in that section, and Tippecanoe county NAD 83 SSURGO soils. Each file is a zip file and must be unzipped.

Arcview GIS uses shapefiles to represent area shapes in a map. Each shapefile can contain thousands of shapes and acts as a separate layer or theme in an ArcView project. The rivers and streams shapefile and the roads shapefile downloaded for this project encompass the entire state of Indiana. The Wetlands shapefile encompassed a large section of central Indiana and central Illinois.

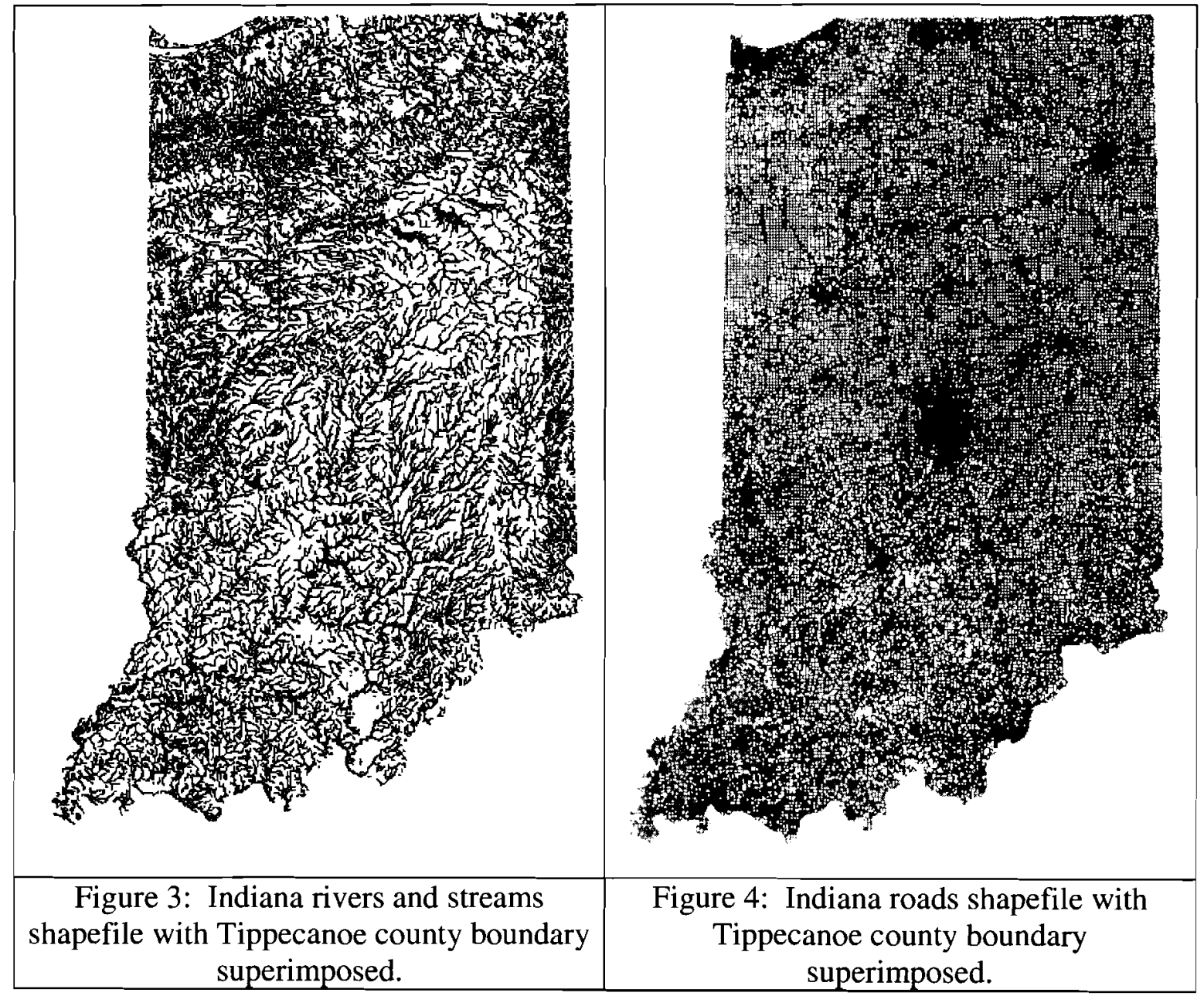




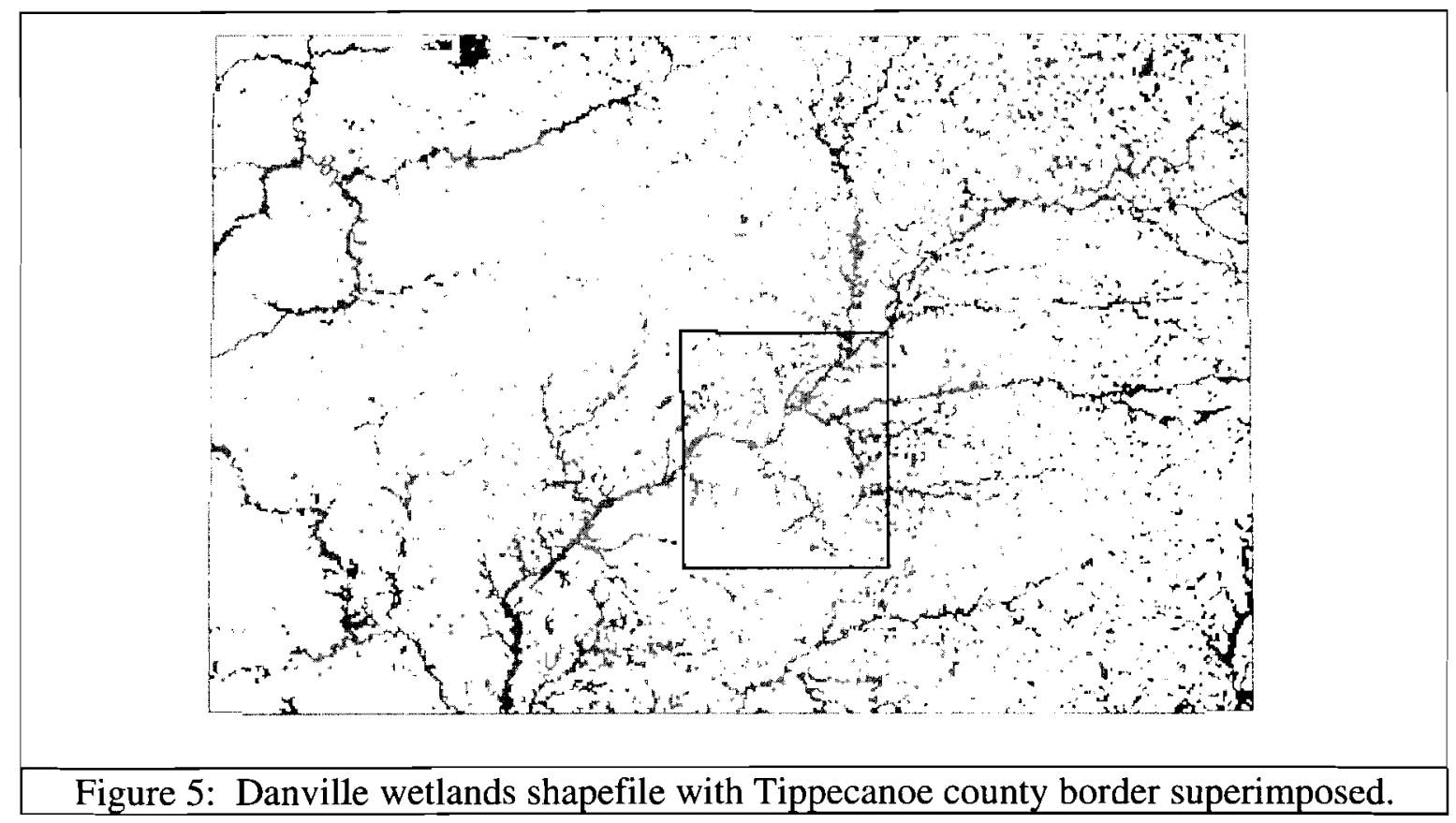

ArcView GIS uses what are called extensions to perform various functions that the basic program cannot do. An extension must be activated or brought into the ArcView project in order to be able to use it. Geoprocessing Wizard is an extension that was used extensively in this project. This extension allows themes to be merged, intersected, unioned, clipped, or dissolved with each other. The Tippecanoe county shapefile was used to clip the desired areas of all three themes pictured above. This clipping resulted in streams, roads, and wetland shapefiles for just the Tippecanoe county area. These three shapefiles are pictured below. 

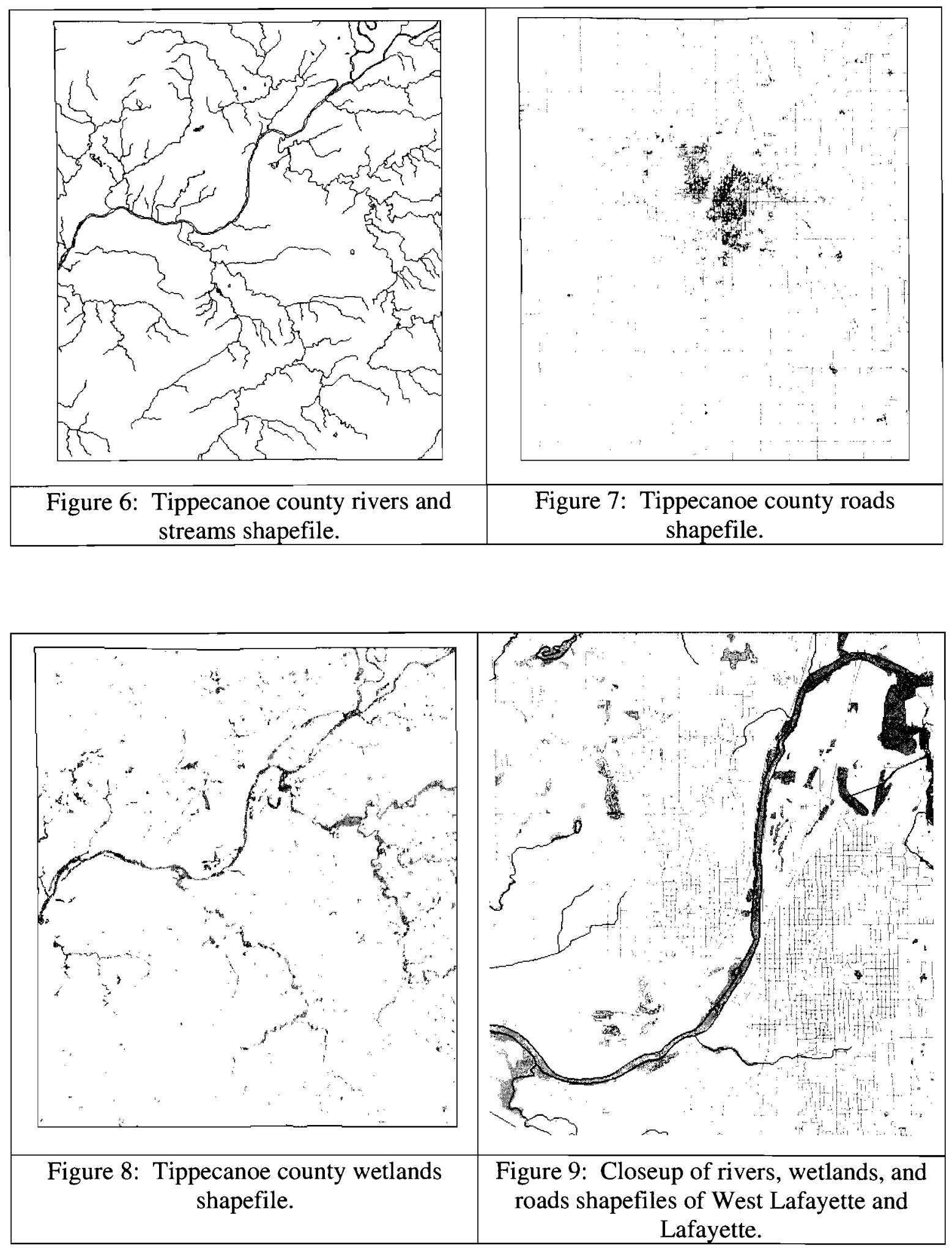

Every shapefile or theme in ArcView has a table or spreadsheet of data associated with it. Every shape within the shapefile constitutes one row in the table. The columns 
are made up of attributes such as area, perimeter, etc. The SSURGO soils shapefile was used to develop a map of hydric soils because the SSURGO table has an attribute called 'hydric' which indicated whether a particular shape (corresponding to an area of land) in the soils shapefile is hydric or not. This was accomplished by using an ArcView GIS function called Query Builder which allows the search of a shapefile's attributes. In this case all shapes whose hydric attribute was " $Y$ " was selected (highlighted in yellow) as can be seen in the figure below. This group of selected shapes was then converted into a new shapefile which is the hydric soil shapefile pictured below.

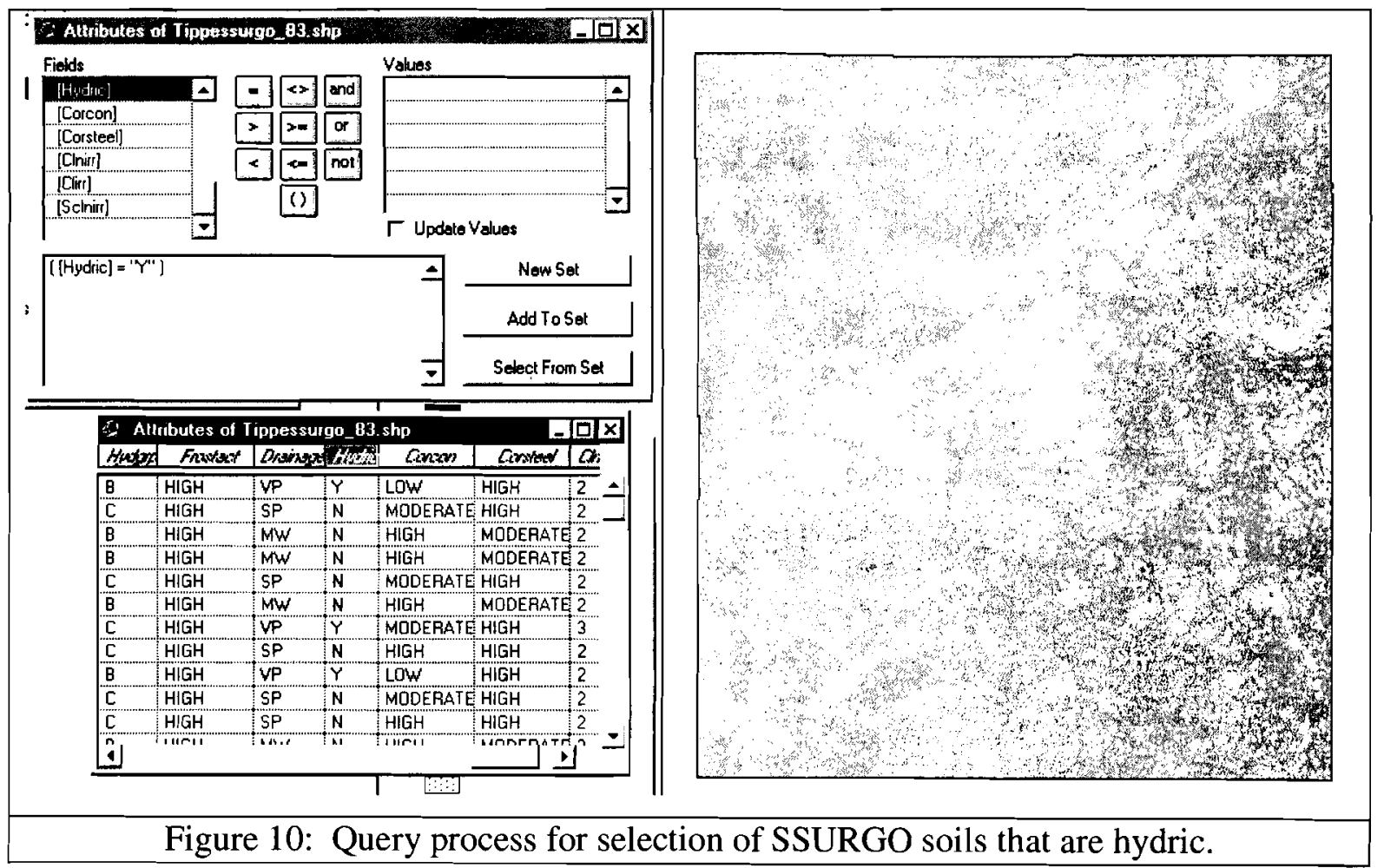




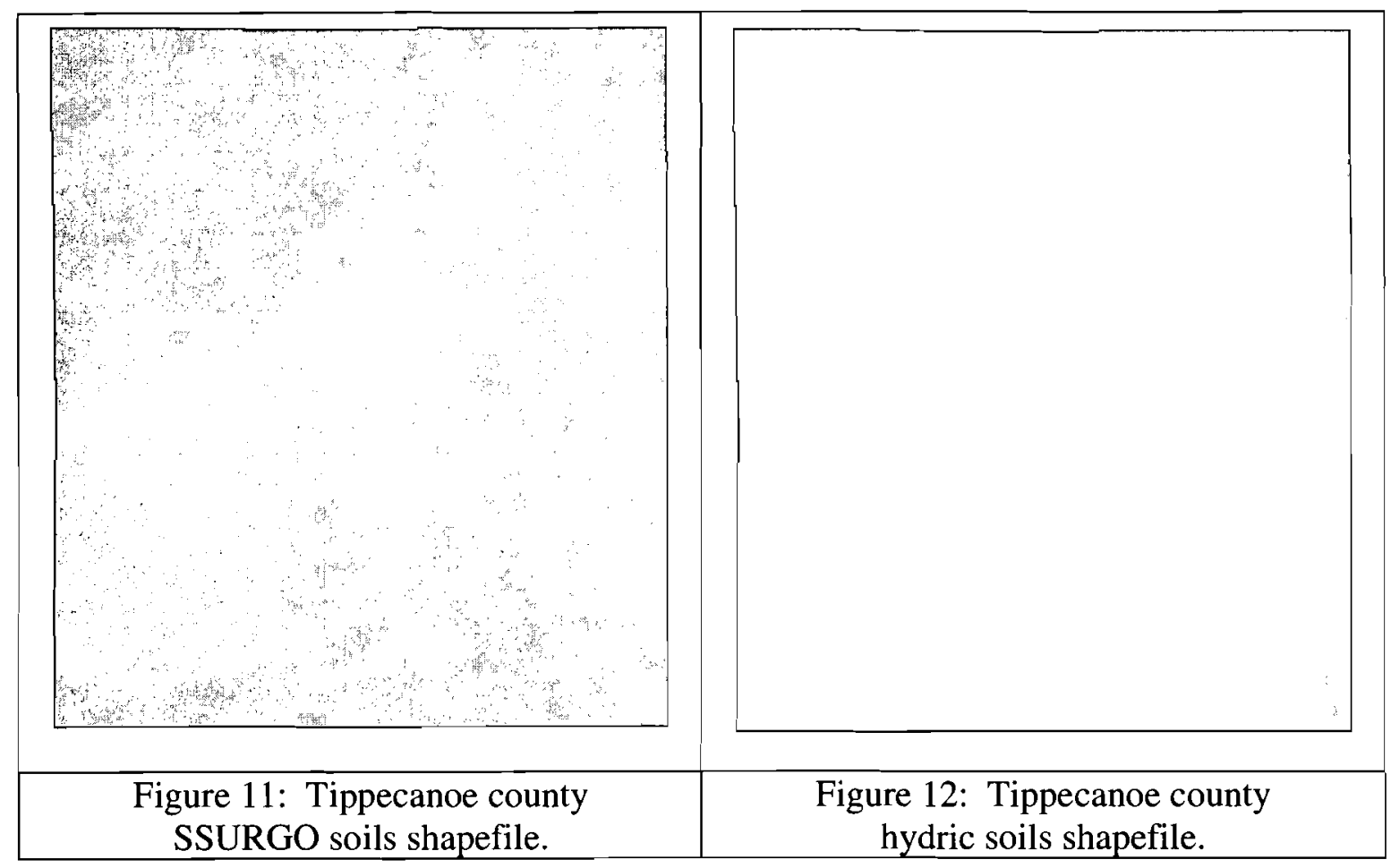

The next step was to create a shapefile of the state and federal roads within Tippecanoe County. The Tippecanoe county roads shapefile contains all roads within the county with no way of easily separating state and federal roads from county roads. Thus the only way to identify state and federal roads is to go in and individually identify and select each shape, a line segment in this case, that is part of a state or federal road. For a reference a Tippecanoe county fold out map, published by UniversalMAP and available in local gas stations and convenient stores, was used. Each road consists of many line segments and the level of detail requires extensive use of the zooming features of ArcView GIS to be able to see clearly. After an entire stretch of road is highlighted using the selection feature in ArcView GIS, it is converted to a new shapefile. After all the state and federal road shapefiles have been created then they are unioned into one single shapefile. The figures below show parts of this time consuming process. 


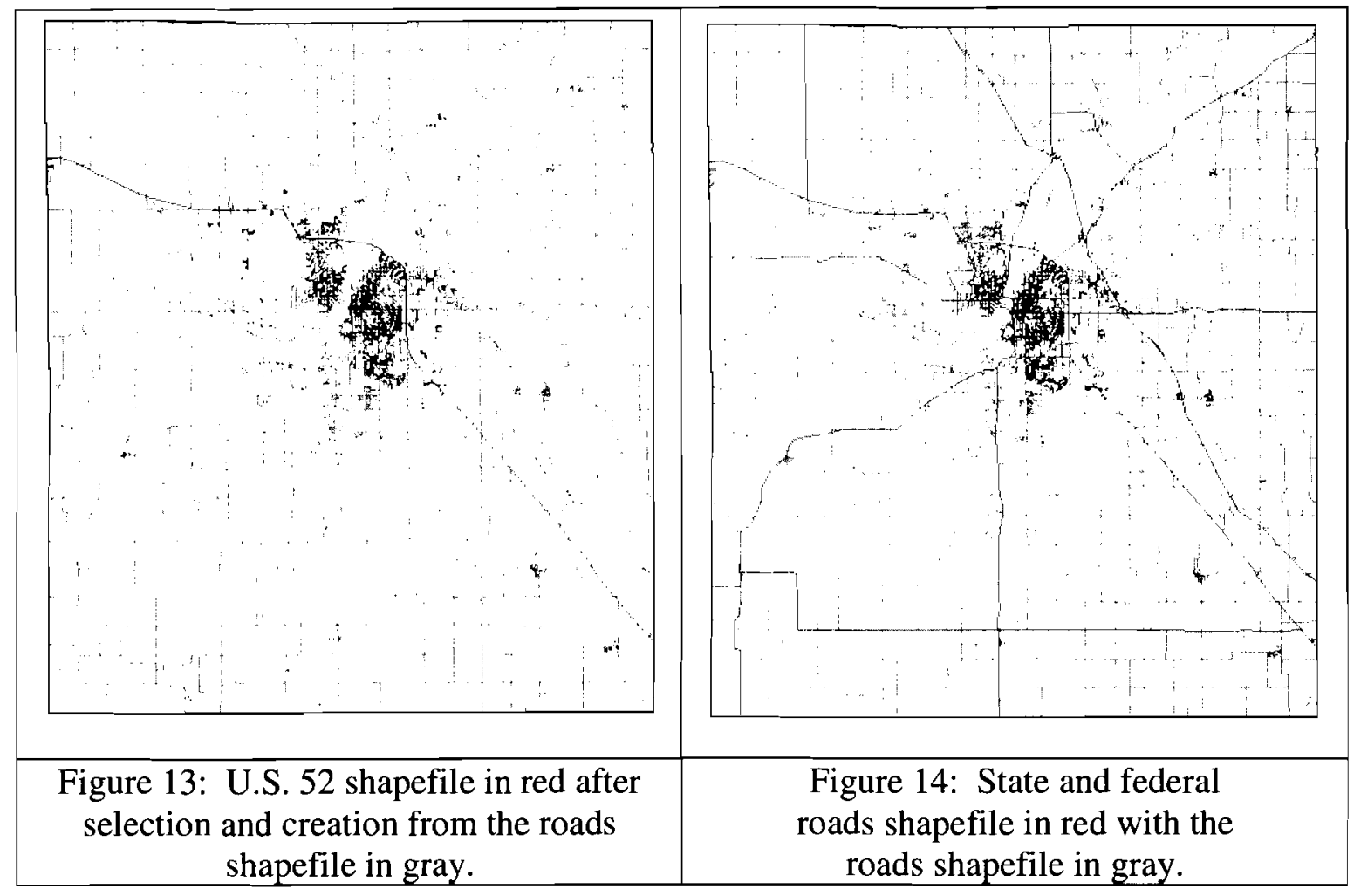

Next 500 feet and 1000 feet buffer shapefiles were created around state and federal roads. This was accomplished using the create buffers function of ArcView GIS.

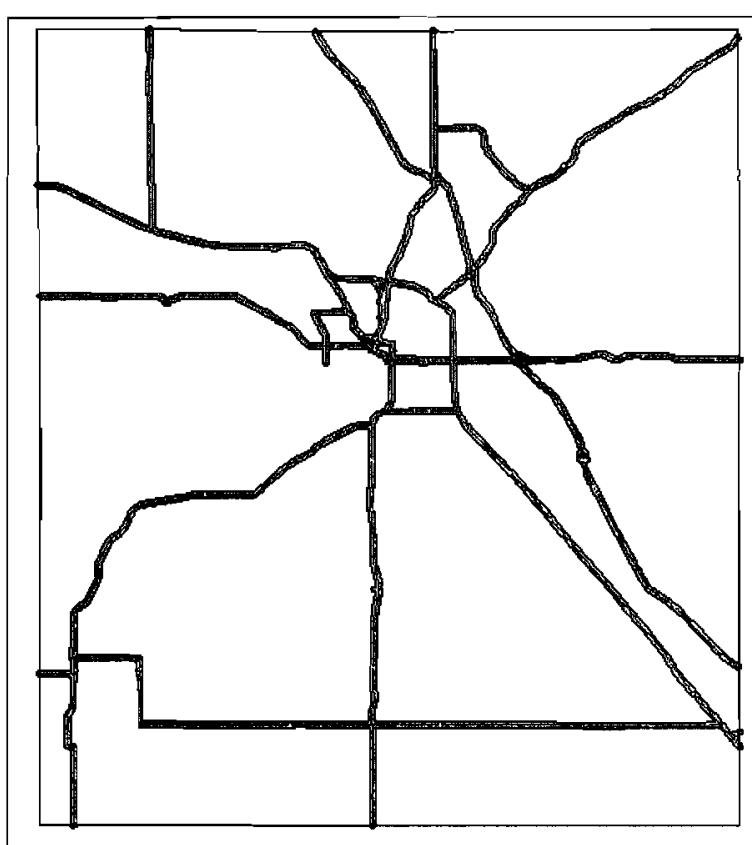

Figure 15: $500 \mathrm{ft}$. buffer shapefile around state and federal roads.

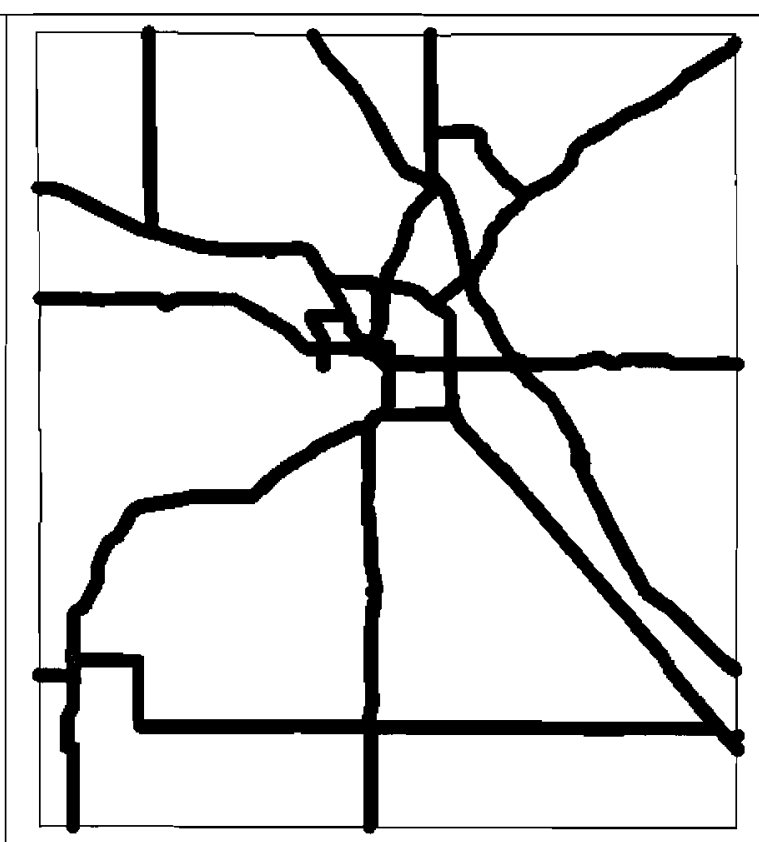

Figure 16: $1000 \mathrm{ft}$. buffer shapefile around state and federal roads. 
The purpose of the buffer shapefiles is to gather information about the state of wetlands within 500 feet and 1000 feet of state and federal roads. This was accomplished by clipping the wetlands and hydric soil shapefiles with each buffer and creating new shapefiles.

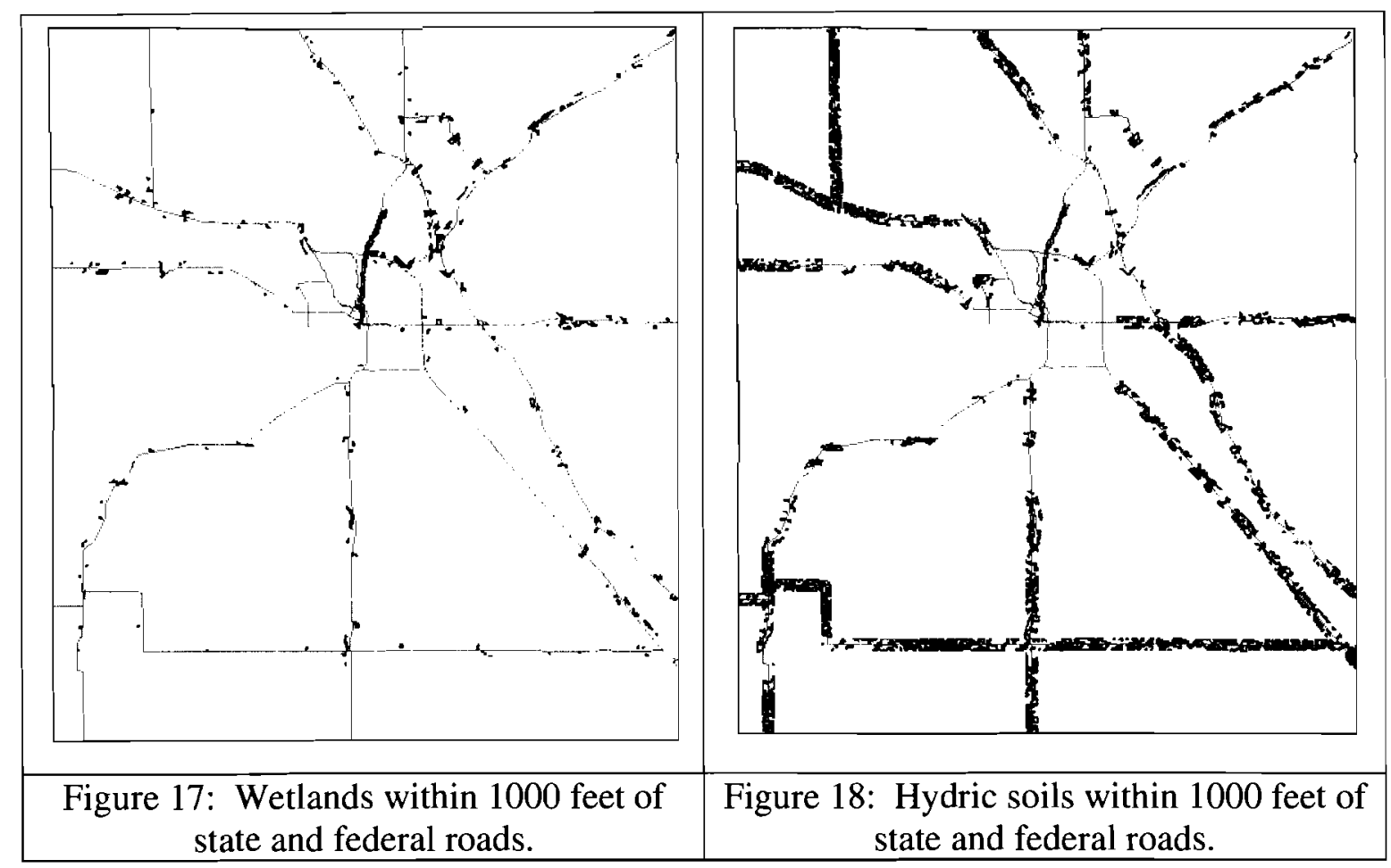

After this process is completed, several useful shapefiles exist for Tippecanoe County. These include wetlands, wetlands within 500 feet of state and federal roads, wetlands within 1000 feet of state and federal roads, hydric soils, hydric soils within 500 feet of state and federal roads, hydric soils within 1000 feet of state and federal roads, and the county shapefile. Another ArcView GIS extension was used at this point, Xtools extension - meters/acres version. Xtools contains a valuable tool that allows the area of each shape within a shapefile to be calculated. For example the area of each wetland in the wetlands shapefile can be calculated with Xtools. The area of these buffer shapefiles were determined by first clipping the buffers with the county border and then calculating the area of the buffer using Xtools.

The next step is to quantify the area data in a spreadsheet. Using Microsoft Excel the table associated with each shapefile, a .dbf file, can be opened and converted to excel files if desired. A basic sum operation can be run on the column of data in the table that contains the area for each shape in the shapefile. For example the area of all of the 
wetlands within Tippecanoe County can be found in this fashion. This completes the first method for data analysis.

This same process was carried out for Laporte County and other counties in Indiana. The following images show some results for Laporte County.
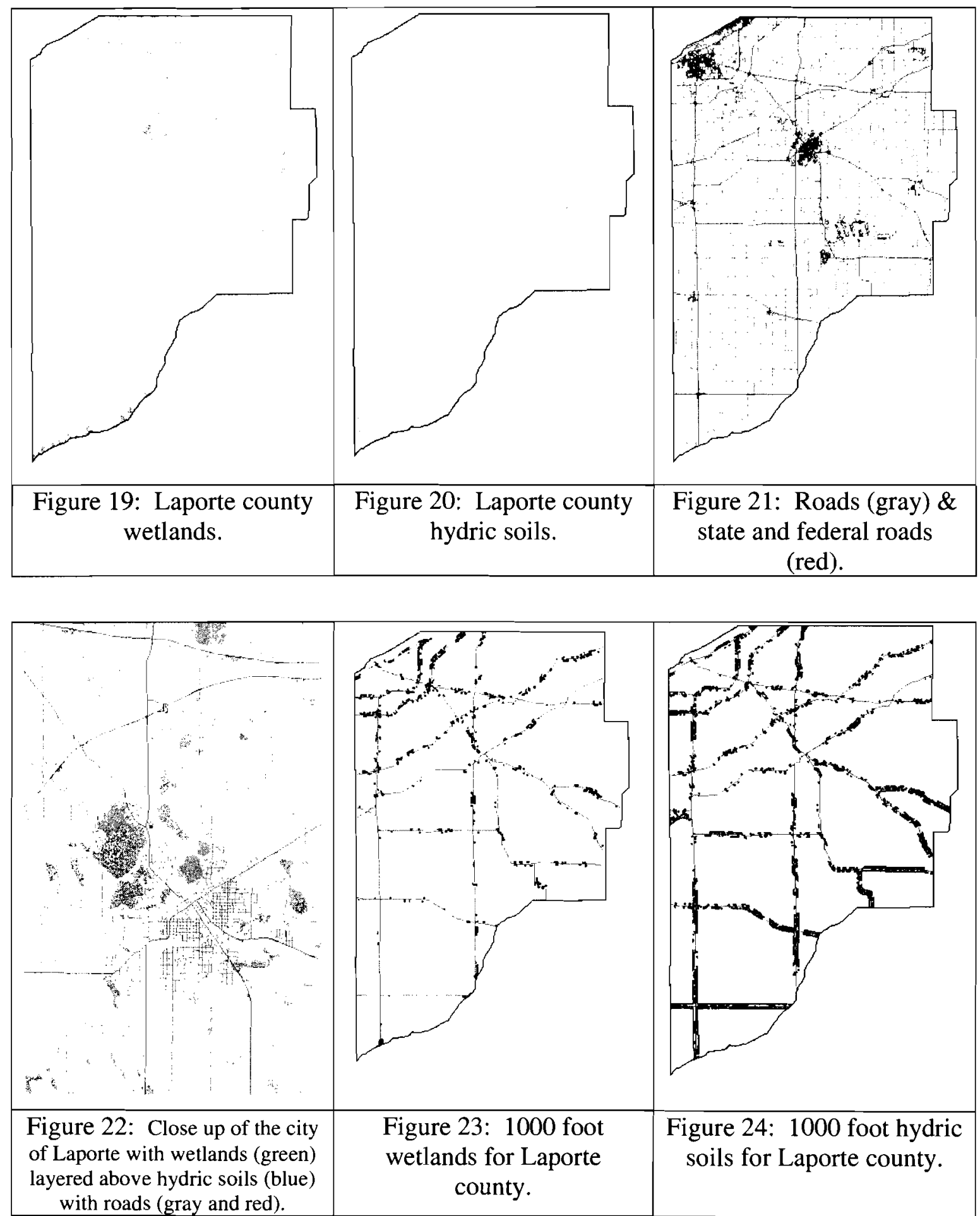
The second method entails acquiring wetland and hydric soil data for counties around the nation. CAAGIS data could not be used for this purpose because CAAGIS only covers Indiana counties. Thus NWI wetlands and NRCS SSURGO data was used. For demonstration purposes, the development of data for Buena Vista County in Iowa will be discussed as a representative case.

After proceeding through the NWI web pages mentioned above in the source section of this paper, selecting the proper county, wetlands and county ESRI files were downloaded in a zip file and unzipped. The unzipped files are then brought directly into the ArcView project for Buena Vista County by adding new themes. The wetland files must then be merged into one theme using Geoprocessing Wizard.

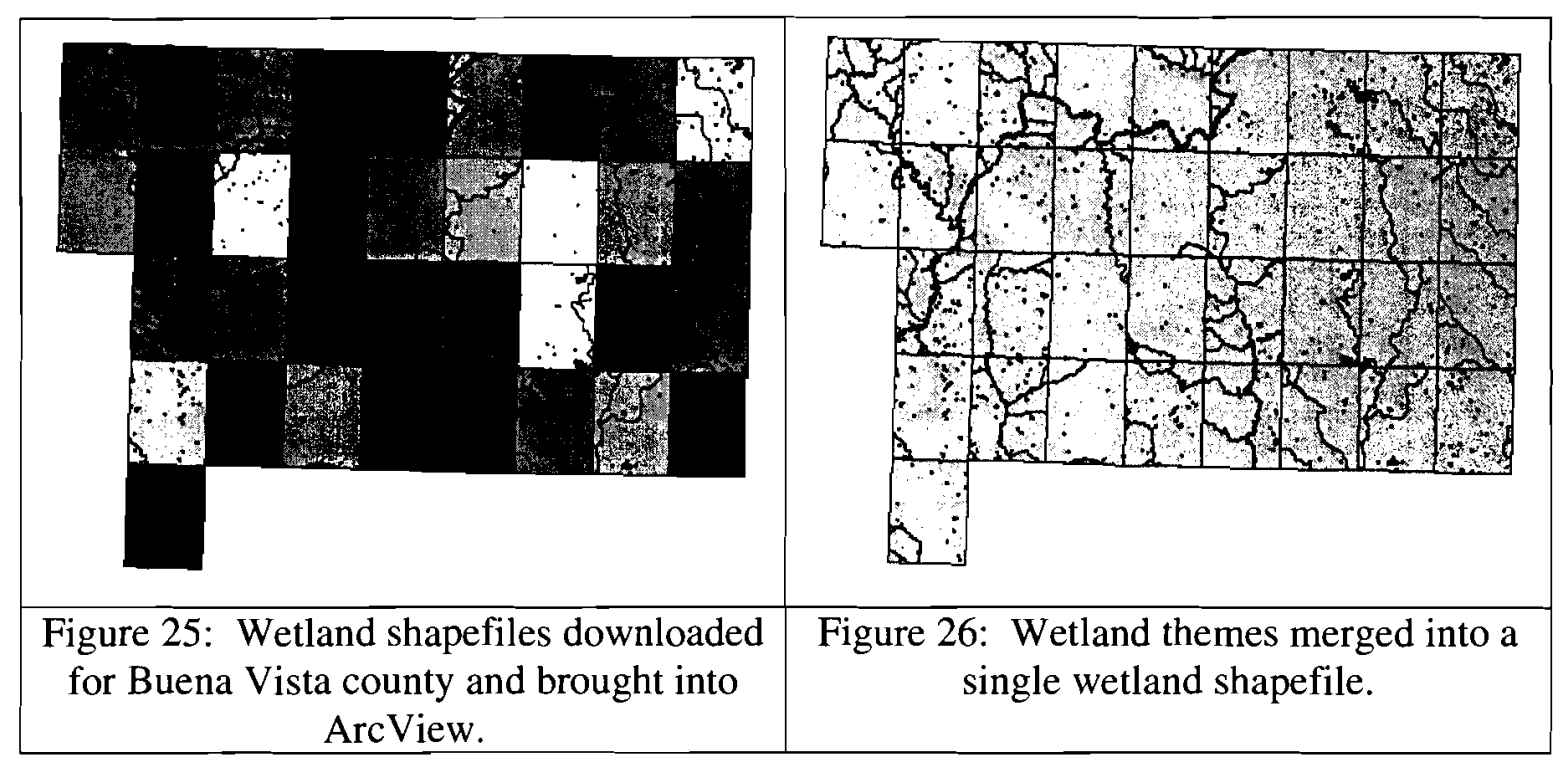

Next the Buena Vista County shapefile is used to clip the merged wetlands shapefile creating a new shapefile of the wetlands within Buena Vista County. This clipped wetlands shapefile contains shapes for both wetlands and uplands which are nonwetlands. Using the Query Builder all of the shapes that are uplands, where attribute equals "U", are selected. The reverse selection tool was then used so that all other shapes, the wetlands, are selected and all uplands are unselected. These selected wetlands are then converted to a new shapefile, which contains only wetlands for Buena Vista County. 


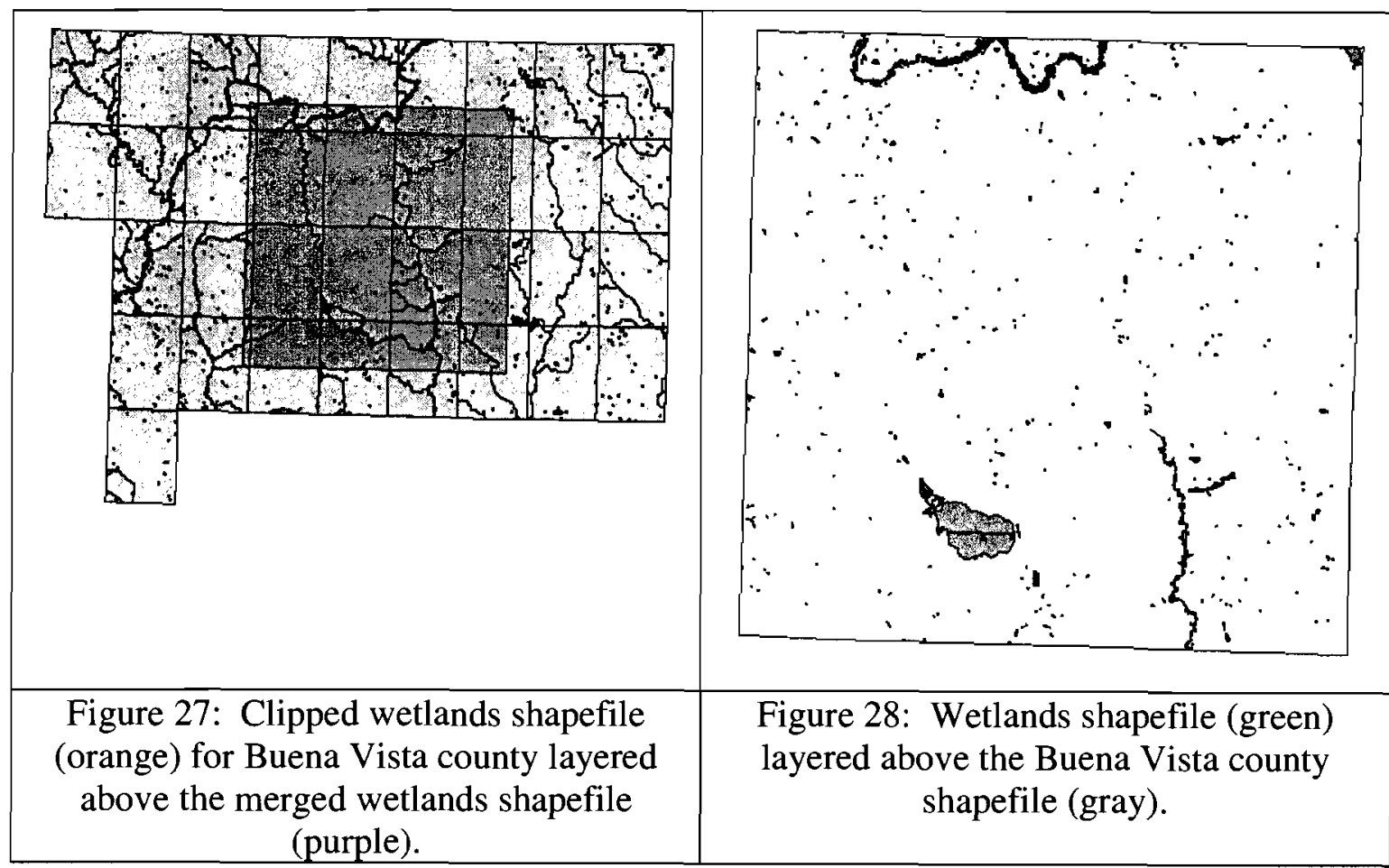

An hydric soils shapefile was developed next. The page for locating the download button for data from Buena Vista County was found using the steps mentioned earlier in the source section of this paper. The zip files downloaded were cov.zip, an ArcInfo coverage file, which is basically the digitized map, and tab.zip, which is a table or spreadsheet of data about shapes, lines, and points, in the coverage file. These files were then unzipped.

The coverage file contains many different files, but three basic files exist. Point shapefiles end in a ' $p$ ', line shapefiles end in a ' 1 ', and area shapefiles end in an ' $a$ '. It is the area shapefiles that were important for this project and these were added to the Buena Vista ArcView project as new themes/shapefiles. These shapefiles must be merged using the Geoprocessing Wizard. 


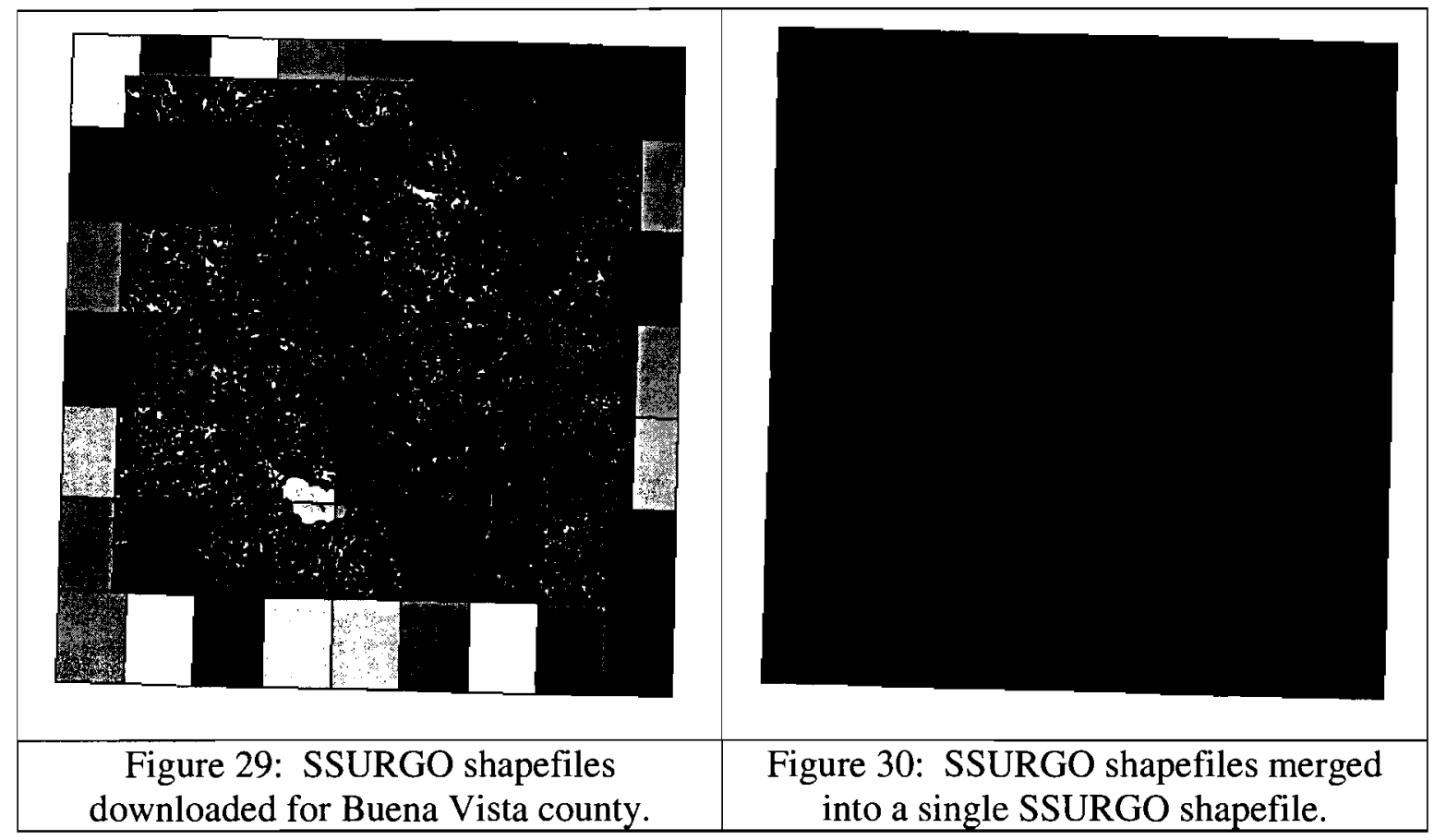

The county shapefile acquired earlier with the NWI data was then used to clip the SSURGO data using the ArcView extension Geoprocessing Wizard. This produces a shapefile of the soils within Buena Vista County.

Unfortunately the table files associated with the SSURGO shapefiles have limited data. They contain no information on whether the soil is hydric or not. This is why the tab.zip file was also downloaded for Buena Vista County. This tab file, short for table, contains several tables related to the SSURGO soil shapefiles, but they must first be brought into ArcView GIS and joined to the limited table the SSURGO soil shapefile already possesses. To accomplish this the table titled "comp", which contains hydric information, is opened in Microsoft Excel. This table is then saved as comp.dbf so it can be opened in ArcView. After the comp.dbf table is opened in ArcView it must be joined to the merged SSURGO shapefile's table. This process is too complicated to describe here, but once the two tables are joined the merged SSURGO shapefile contains a single larger table which now contains the hydric information.

Using Query Builder on the new table, those soils where the hydric attribute equals " $Y$ " for yes or " $U$ " for unknown is selected. This highlighted data was converted to a new shapefile, the hydric soils for Buena Vista County. 
A note of some importance is discussed here. The " $U$ " data was selected even though it is not hydric because examination of SSURGO shapefiles indicated that this value was used to represent large bodies of water, mainly lakes. Why these soils are not classified as hydric was not determined, however they are also not classified as "N", nonhydric. In addition these large bodies of water are classified as wetlands in the NWI data. Since the point of this method is to compare areas of hydric soils to that of wetlands it was determined that leaving out large areas that are certainly hydric by the nature of lying underwater would skew the results. Thus these soils were added to the hydric soils shapefile.

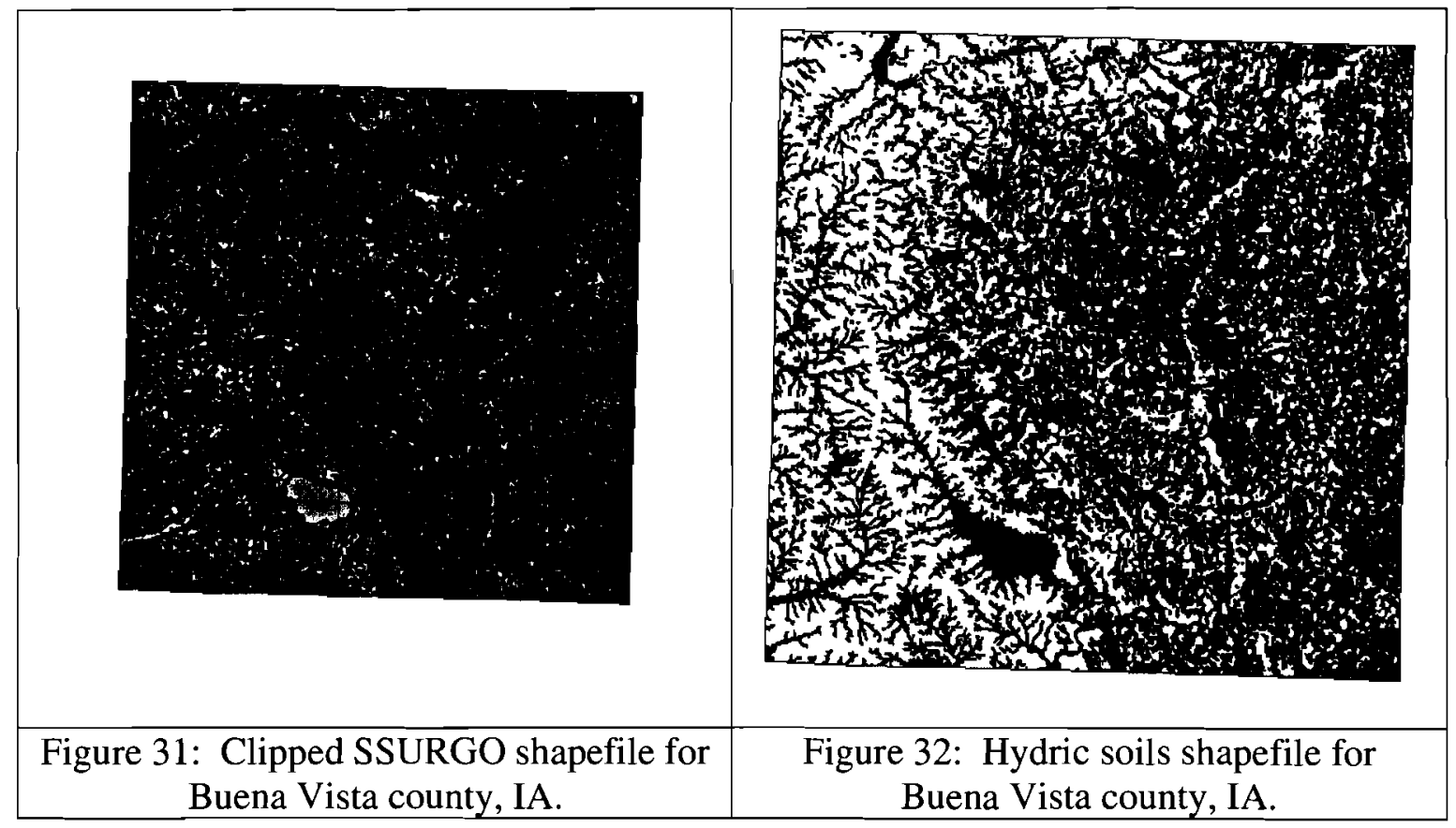

Next the Xtools extension was used to calculate the areas of the county shapefile, wetlands shapefile, and hydric soils shapefile. Microsoft Excel was then used to access the .dbf table files associated with these shapefiles and total areas of all wetlands and all hydric soils could be calculated.

This method was carried out on thirteen other counties in various states around the eastern half of the nation. The results for another county, Wright County in Minnesota, is pictured below. 


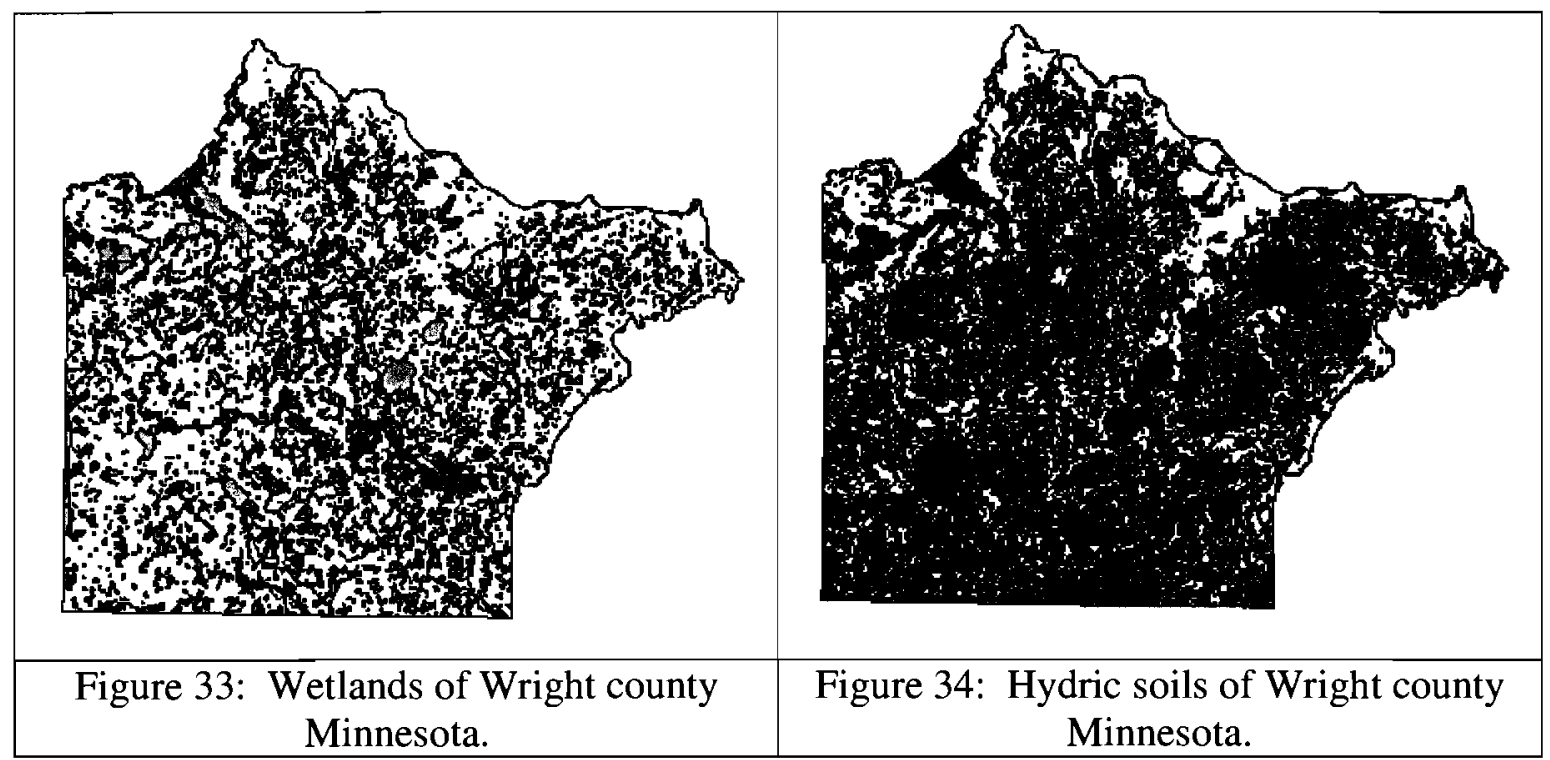

Due to some discrepancies with some of the CAAGIS data, the second method described above was used in the revisions of the Indiana counties examined in detail, previously performed using method one. County and wetland themes were created using NWI data. Soils and hydric soils data was created using NRCS SSURGO data. CAAGIS data that was still used included, roads, streams and railroads data. Also the process for creating themes of state and federal roads, 500' and 1000' buffers of these roads, and wetlands and hydric soils within these buffers remains the same as described above in the first method. 


\section{RESULTS and DISCUSSION}

The results for the Indiana counties examined in detail are listed below:

\begin{tabular}{|c|c|c|c|c|c|c|c|c|c|}
\hline \multirow[b]{4}{*}{ COUNTY } & \multirow{4}{*}{$\begin{array}{c}\text { County } \\
\text { Area } \\
\text { (acres) }\end{array}$} & \multirow{4}{*}{$\begin{array}{c}\text { Area of } \\
500^{\prime} \text { Buffer } \\
\text { Around } \\
\text { Roads } \\
\text { (acres) }\end{array}$} & \multirow{4}{*}{\begin{tabular}{|c} 
Area of \\
$1000^{\prime}$ Buffer \\
Around \\
Roads \\
(acres)
\end{tabular}} & \multirow{4}{*}{$\begin{array}{c}\text { Wetlands } \\
\text { w/in 500' } \\
\text { Buffer } \\
\text { (acres) }\end{array}$} & \multirow{4}{*}{$\begin{array}{c}\text { Wetlands } \\
\text { within 500' } \\
\text { Buffer/ } \\
\text { Area of } \\
500^{\prime} \text { Buffer } \\
(\%)\end{array}$} & \multirow{4}{*}{$\begin{array}{c}\text { Wetlands } \\
\text { w/in } 1000^{\prime} \\
\text { Buffer } \\
\text { (acres) }\end{array}$} & \multirow{4}{*}{$\begin{array}{c}\text { Wetlands } \\
\text { within 1000' } \\
\text { Buffer/ } \\
\text { Area of } \\
1000^{\prime} \text { Buffer } \\
(\%)\end{array}$} & \multirow{4}{*}{$\begin{array}{c}\text { Total } \\
\text { Wetlands } \\
\text { (acres) }\end{array}$} & \multirow{4}{*}{$\begin{array}{c}\text { Total } \\
\text { Wetlands } \\
\text { County Area } \\
(\%)\end{array}$} \\
\hline & & & & & & & & & \\
\hline & & & & & & & & & \\
\hline & & & & & & & & & \\
\hline Carroll & 239850 & 12246 & \begin{tabular}{|l|}
24152 \\
\end{tabular} & 265 & $2.2 \%$ & 700 & $2.9 \%$ & 8626 & $\therefore \quad 3.6 \%$ \\
\hline Fountain & 254465 & 11362 & 22298 & 251 & (1) 2.2\% & 579 & 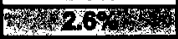 & 10474 & 40 \\
\hline Laporte & 386443 & 28676 & 55879 & 1125 & 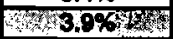 & 3006 & $64064 \%$ & 27821 & \\
\hline Scott & 123284 & 9360 & 18150 & 302 & $3.2 \%$ & 794 & $4.4 \%$ & 8514 & $6.9 \%$ \\
\hline Tippecanoe & 321815 & 20667 & 40158 & 538 & 72.6\% & 1370 & 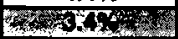 & 13155 & \\
\hline Vermillion & 166232 & 11362 & 22298 & 251 & $2.2 \%$ & 579 & $2.6 \%$ & 6793 & $4.1 \%$ \\
\hline Wayne & 258756 & 16948 & 33088 & 356 & $2 \pi \%$ & 884.5 & 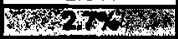 & 7393 & $x^{2}$ \\
\hline
\end{tabular}

Table 1: Results from Indiana counties concerning the prevalence of wetlands near state and federal roads.

\begin{tabular}{|c|c|c|c|c|c|c|c|c|c|}
\hline \multirow[b]{2}{*}{ COUNTY } & \multirow[b]{2}{*}{$\begin{array}{c}\text { County } \\
\text { Area } \\
\text { (acres) }\end{array}$} & \multirow[b]{2}{*}{\begin{tabular}{|c|} 
Area of \\
500 Buffer \\
Around \\
Roads \\
(acres)
\end{tabular}} & \multirow[b]{2}{*}{\begin{tabular}{|c|} 
Area of \\
$1000^{\prime}$ Buffer \\
Around \\
Roads \\
(acres)
\end{tabular}} & \multirow[b]{2}{*}{$\begin{array}{c}\text { Hydric } \\
\text { Soils } \\
\text { w/in 500 } \\
\text { Buffer } \\
\text { (acres) }\end{array}$} & \multirow[b]{2}{*}{\begin{tabular}{|c|} 
Hydric soils \\
withln 500' \\
Buffer/ \\
Area of \\
500' Buffer \\
(\%)
\end{tabular}} & \multirow[b]{2}{*}{$\begin{array}{c}\text { Hydric } \\
\text { Soils } \\
\text { w/in } 1000^{\prime} \\
\text { Buffer } \\
\text { (acres) }\end{array}$} & \multirow[b]{2}{*}{\begin{tabular}{|c|} 
Hydric solls \\
within 1000' \\
Buffer/ \\
Area of \\
1000' Buffer \\
(\%)
\end{tabular}} & \multirow[b]{2}{*}{$\begin{array}{c}\text { Total } \\
\text { Hydric } \\
\text { Soils } \\
\text { (acres) }\end{array}$} & \multirow[b]{2}{*}{$\begin{array}{c}\text { Total } \\
\text { Hydric solls/ } \\
\text { County Area } \\
(\%)\end{array}$} \\
\hline & & & & & & & & & \\
\hline Carroll & 239850 & 12246 & \begin{tabular}{|l|}
24152 \\
\end{tabular} & \begin{tabular}{|l|}
3168 \\
\end{tabular} & $25.9 \%$ & 6498 & $26.9 \%$ & 67851 & $28.3 \%$ \\
\hline Fountain & 254465 & 11362 & 22298 & 1894 & 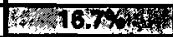 & 3789 & WTo & 57889 & \\
\hline Elkhart & 299246 & 23820 & 46466 & 5011 & $21.0 \%$ & 10651 & $22.9 \%$ & 73055 & $24.4 \%$ \\
\hline Laporte & 386443 & 28676 & 55879 & 7528 & W.628.3\% & 15647 & 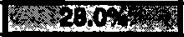 & 134684 & \\
\hline Scott & 123284 & 9360 & 18150 & 4447 & $47.5 \%$ & 8565 & $47.2 \%$ & 57569 & $46.7 \%$ \\
\hline Tippecanoe & 321815 & 20667 & 40158 & 4261 & 120.676 & 8726 & 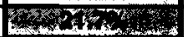 & 81230 & \\
\hline Vermillion & 166232 & 11362 & 22298 & 1894 & $16.7 \%$ & 3789 & $17.0 \%$ & 30671 & $18.5 \%$ \\
\hline Wayne & 258756 & 16948 & 33088 & 1528.7 & 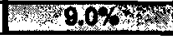 & 3227 & 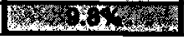 & 28866 & 35 \\
\hline able 2: & & & & & eder & & & & \\
\hline
\end{tabular}




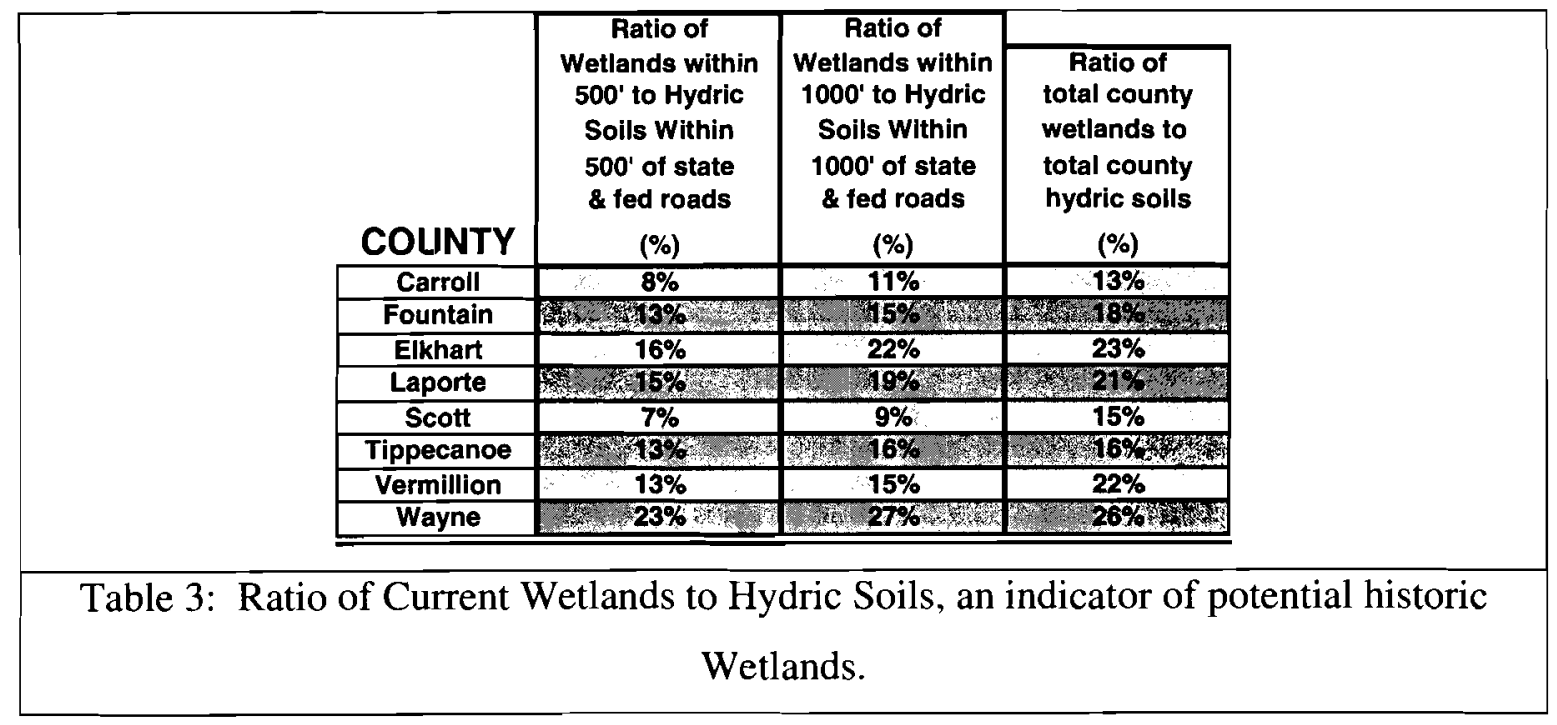

With hydric soils representing the potential for wetlands to have existed in the past, the wetlands to hydric soil ratio provides an indicator of what percentage of wetlands exist today as compared to what may have existed prior to European settlement. In the counties examined the wetlands to hydric ratios are small ranging from $26 \%$ to $13 \%$. This represents an approximate $80 \%$ decline in the amount of wetlands that may have existed at one time.

When only those wetlands and hydric soils near state and federal roads, those INDOT is responsible for, are looked at, the results are similar, but with a further decline in the ratio as proximity to the road increases. This could be do to a couple of factors. One possibility is that road construction has had a negative impact on the prevalence of wetlands. Where road construction went through a wetland, then that land had to be drained and made into a suitable roadbed. But since hydric soils prevalence as well as wetlands prevalence decreases with the proximity of roads, this could also indicate that road construction was undertaken through areas with fewer hydric soils, and thus fewer wetlands, thereby minimizing construction cost and effort required. Whether a soil is an hydric or not should not change over time. The fact that hydric soil prevalence does decrease as proximity to roads increases supports the idea that state and federal roads were, to some degree, constructed to avoid hydric soils/historic wetlands. The following two figures summarize the prevalence of wetlands and hydric soils as they near state and federal roads. 


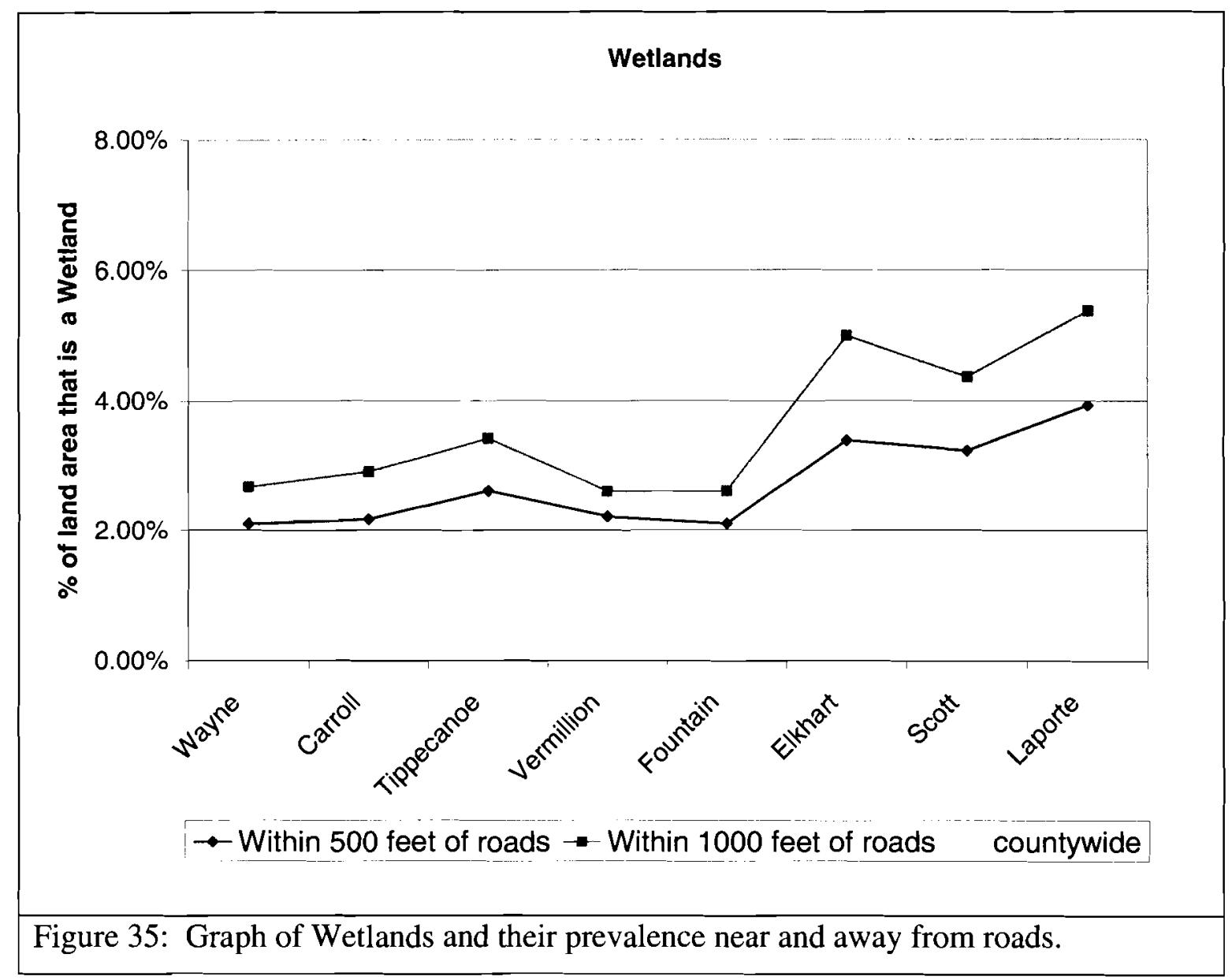




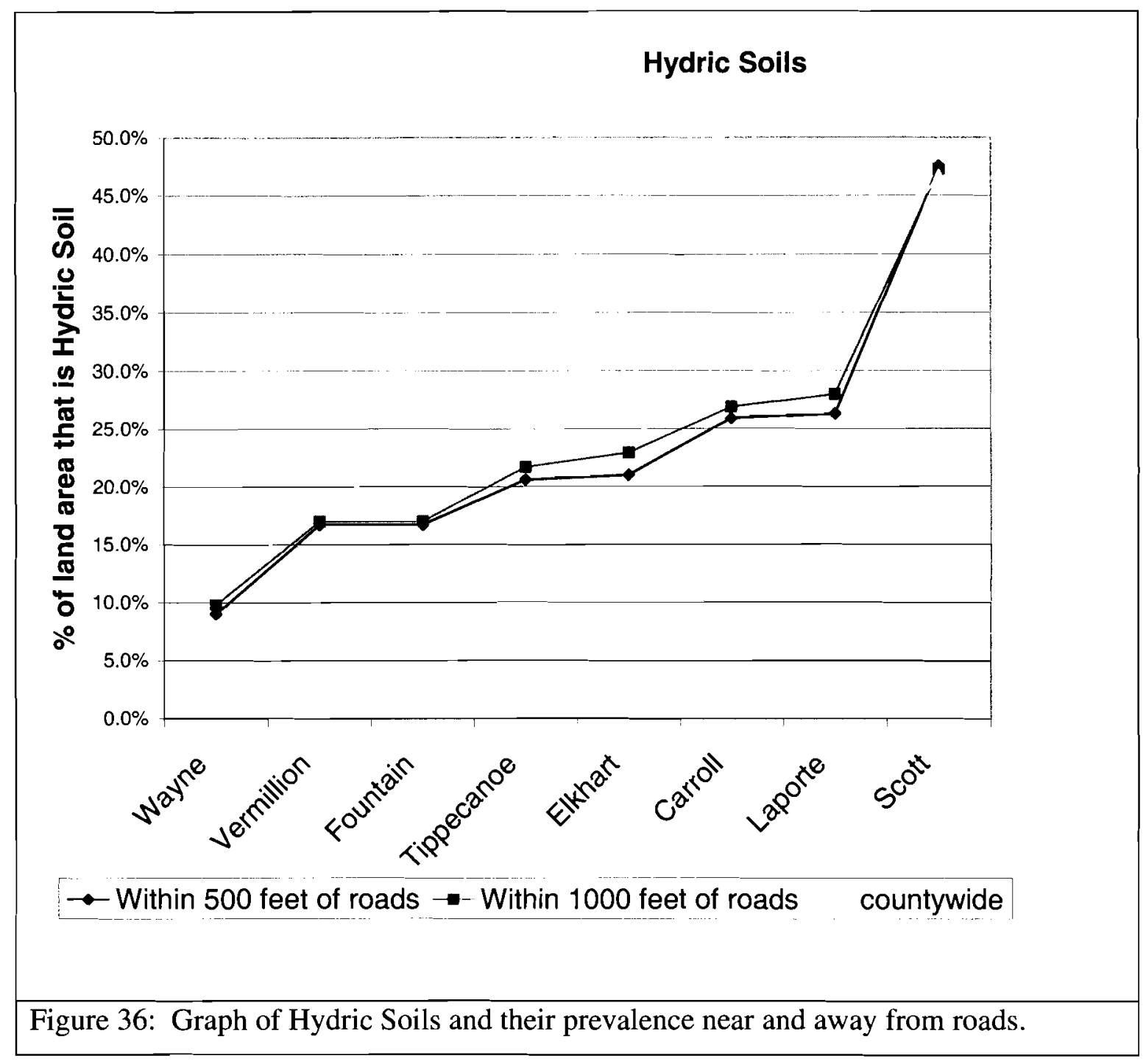

But in any case, the data indicates that the majority of wetland loss occurred separate from state and federal road construction. Countywide the potential losses range from $74 \%$ to $87 \%$, a dramatic decline. Proximity to roads only increases this loss only another few percent, a figure that pales in comparison to the huge loss already indicated.

The next analysis which centered on examining agricultural intensity within a county and comparing that to the amount of wetlands remaining in that county from what potentially existed at one time is summarized in the figure below. 


\begin{tabular}{|c|c|c|c|c|c|c|c|c|c|c|}
\hline State & County & $\begin{array}{c}\text { area } \\
\text { (acres) }\end{array}$ & $\begin{array}{c}\text { (nemente } \\
(\%)\end{array}$ & $\begin{array}{c}\text { farm } \\
\text { (acres) }\end{array}$ & $\begin{array}{c}\text { county area } \\
\text { (including lakes) } \\
\text { (acres) }\end{array}$ & $\begin{array}{l}\text { hydric } \\
\text { (acres) }\end{array}$ & $\begin{array}{l}\text { wetlands } \\
\text { (acres) }\end{array}$ & $\begin{array}{c}\text { iwethydric } \\
(\%)\end{array}$ & $\begin{array}{c}\text { (hyd/total) } \\
(\%)\end{array}$ & $\begin{array}{c}\text { (wet/total) } \\
(\%)\end{array}$ \\
\hline \multirow[t]{4}{*}{ Illinois } & Edgar & 399095 & 88.3 & 352,401 & 399,198 & 148736 & 3689 & 92.5 & 37.3 & 0.9 \\
\hline & Champaign & 638205 & 89 & 567697 & 638,072 & 357219 & 6396 & 1.8 & 56.0 & 1.0 \\
\hline & McHenry & 386654 & 62.7 & 242484 & 390,947 & 108374 & 54266 & 50.1 & 27.7 & 13.9 \\
\hline & Franklin & 179588 & 68.1 & 263743 & 276,067 & 69517 & 38157 & 54.9 & 25.2 & 13.8 \\
\hline \multirow[t]{3}{*}{ lowa } & Buena Vista & 367885 & 97 & 356751 & 371,206 & 133170 & 6128 & 4.6 & 35.9 & 1.7 \\
\hline & Humboldt & 278037 & 92.6 & 257411 & 278,706 & 158068 & 4600 & 2.9 & 56.7 & 1.7 \\
\hline & Van Buren & 310561 & 82.8 & 257227 & 313,760 & 83685 & 9031 & 10.8 & 26.7 & 2.9 \\
\hline \multirow[t]{2}{*}{ Minnesota } & Sherburne & 279403 & 37.6 & 117701 & 288,429 & 70594 & 60984 & 86.4 & 24.5 & $\overline{21.1}$ \\
\hline & Wright & 422934 & 59.5 & 251832 & 456,901 & 170574 & 141385 & 82.9 & 37.3 & 30.9 \\
\hline Missouri & Wright & 436701 & 71.5 & 312388 & 436,911 & 6496.5 & 2756 & 42.4 & 1.5 & 0.6 \\
\hline New Jersey & Hunterdon & 275261 & 38.2 & 105230 & 279,940 & 17481 & 10100 & 57.8 & 6.2 & 3.6 \\
\hline New York & St. Lawrence & 1718863 & 23.1 & 396406 & $1,383, \overline{314}$ & 292279 & 222107 & 76.0 & 21.1 & 16.1 \\
\hline \multirow[t]{2}{*}{ North Carolina } & Hyde & 392208 & 24.3 & 95327 & 443,965 & 444079 & 289879 & 65.3 & 100.0 & 65.3 \\
\hline & Johnston & 506868 & 41.6 & 211011 & 509,656 & 141103 & 68566 & 48.6 & 27.7 & 13.5 \\
\hline \multirow[t]{12}{*}{ Indiana } & Laporte & 382897 & 64.7 & 247756 & 386,443 & 134685 & 27821 & 20.7 & 34.9 & 7.2 \\
\hline & Tippecanoe & 319896 & 75.5 & 241532 & 321,707 & 81230 & 13155 & 16.2 & 25.2 & 4.1 \\
\hline & Elkhart & 296856 & 61.6 & 182771 & 299,246 & 73055 & 17131 & 23.4 & 24.4 & 5.7 \\
\hline & Carroll & 238251 & 91.6 & 218170 & 239,849 & 67851 & 8626 & 12.7 & 28.3 & 3.6 \\
\hline & Delaware & 251720 & 68.9 & 176443 & 253,304 & 94217 & 7329 & 7.8 & 37.2 & 2.9 \\
\hline & Fountain & 253264 & 80.8 & 204554 & 254,465 & 57889 & 10474 & 18.1 & 22.7 & 4.1 \\
\hline & Scott & 121856 & 47.1 & 57372 & 123,284 & 57569 & 8514 & 14.8 & 46.7 & 6.9 \\
\hline & Vermillion & 164418 & 71.8 & 118065 & 166,232 & 30671 & 6793 & 22.1 & 18.5 & 4.1 \\
\hline & Wayne & 258288 & 66.9 & 172860 & 258,756 & 28866 & 7393 & 25.6 & 11.2 & 2.9 \\
\hline & Perry & 244104 & 34.5 & 84251 & 247,066 & 6184 & 5506 & 89.0 & 2.5 & 2.2 \\
\hline & Harrison & 310561 & 52 & 161378 & 311,399 & 3023 & 4832 & 159.8 & 1.0 & 1.6 \\
\hline & Owen & 246538 & 43.5 & 107265 & 248,014 & 6306 & 8412 & 133.4 & 2.5 & 3.4 \\
\hline & $3 \quad 14$ & & & & he encter & 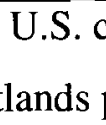 & 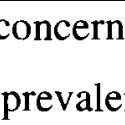 & 政 & el & \\
\hline
\end{tabular}

There are two chief figures, both highlighted, to observe in the above spreadsheet. The first is the percent farms which is a measure of how much of the land in that county is used as farmland or in other words a measure of the agricultural intensity within that county. The second figure to note is the wetlands to hydric soils ratio, which indicates the percent of current wetlands to that of the potential historic wetlands. 


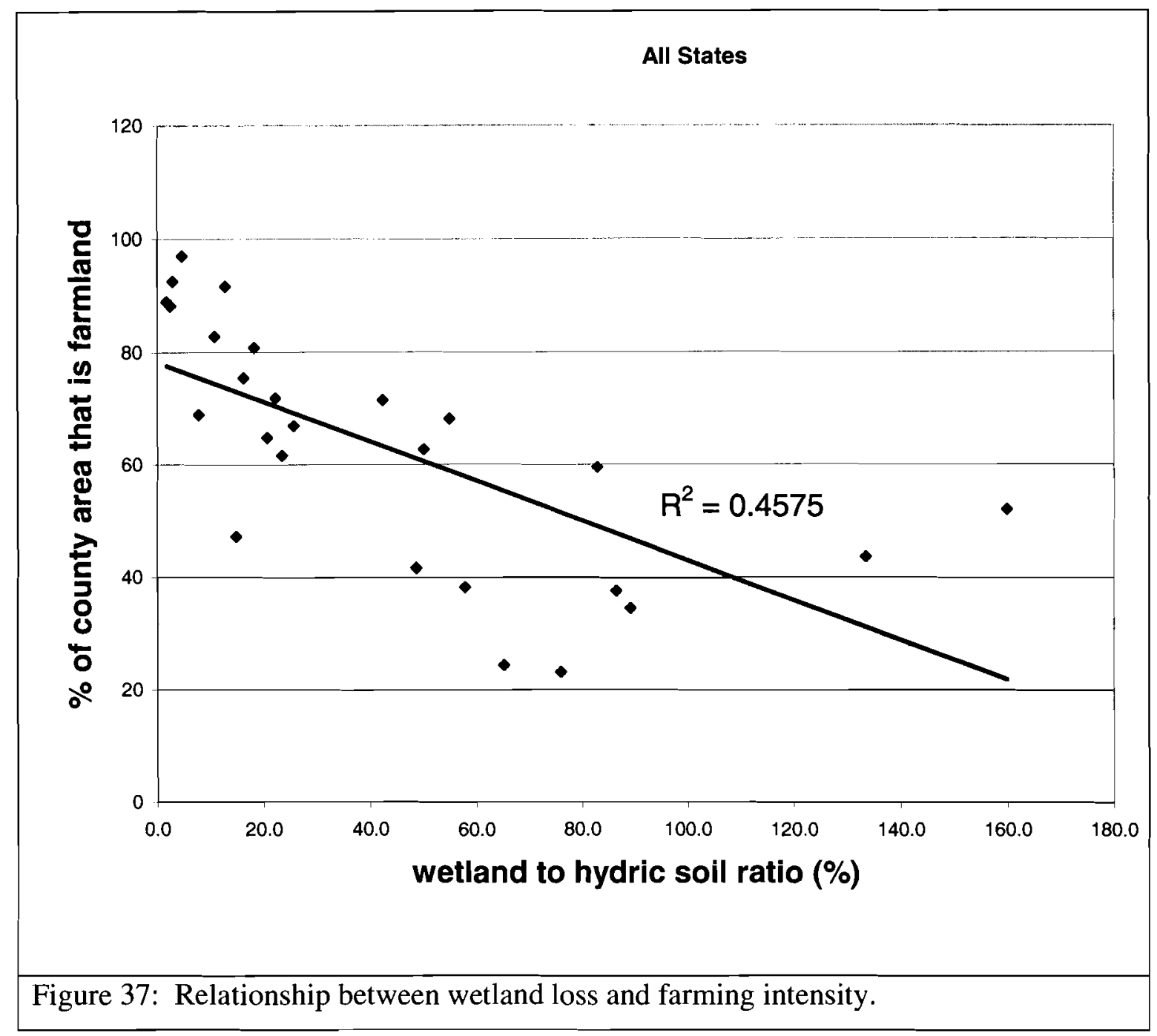

When these two factors are graphed against one another, a trend is seen. As the amount of farmland decreases, the amount of potential historic wetlands still in existence increases. While this relationship is not precisely linear, it would not be expected to be since there are many factors potentially affecting wetland losses.

The next analysis which centered on examining forest cover within a county and comparing that to the amount of wetlands remaining in that county from what potentially existed at one time is summarized in the figure below. 


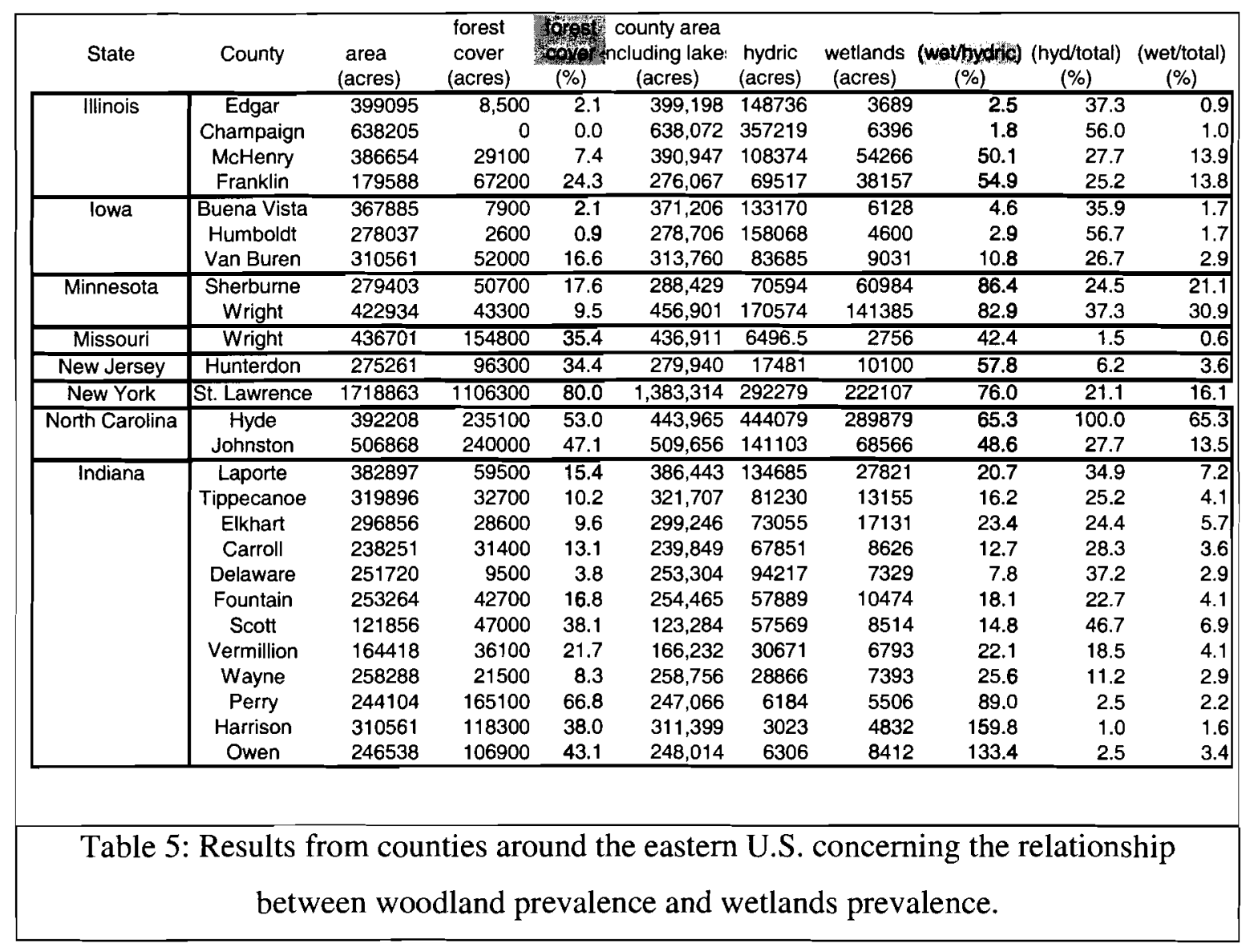

There are two chief figures, both highlighted, to observe in the above spreadsheet. The first is the percent forest cover, which is a measure of how much of the land is covered with forest. The second figure to note is the wetlands to hydric soils ratio, which, as mentioned above, indicates the percent of current wetlands to that of the potential historic wetlands. 


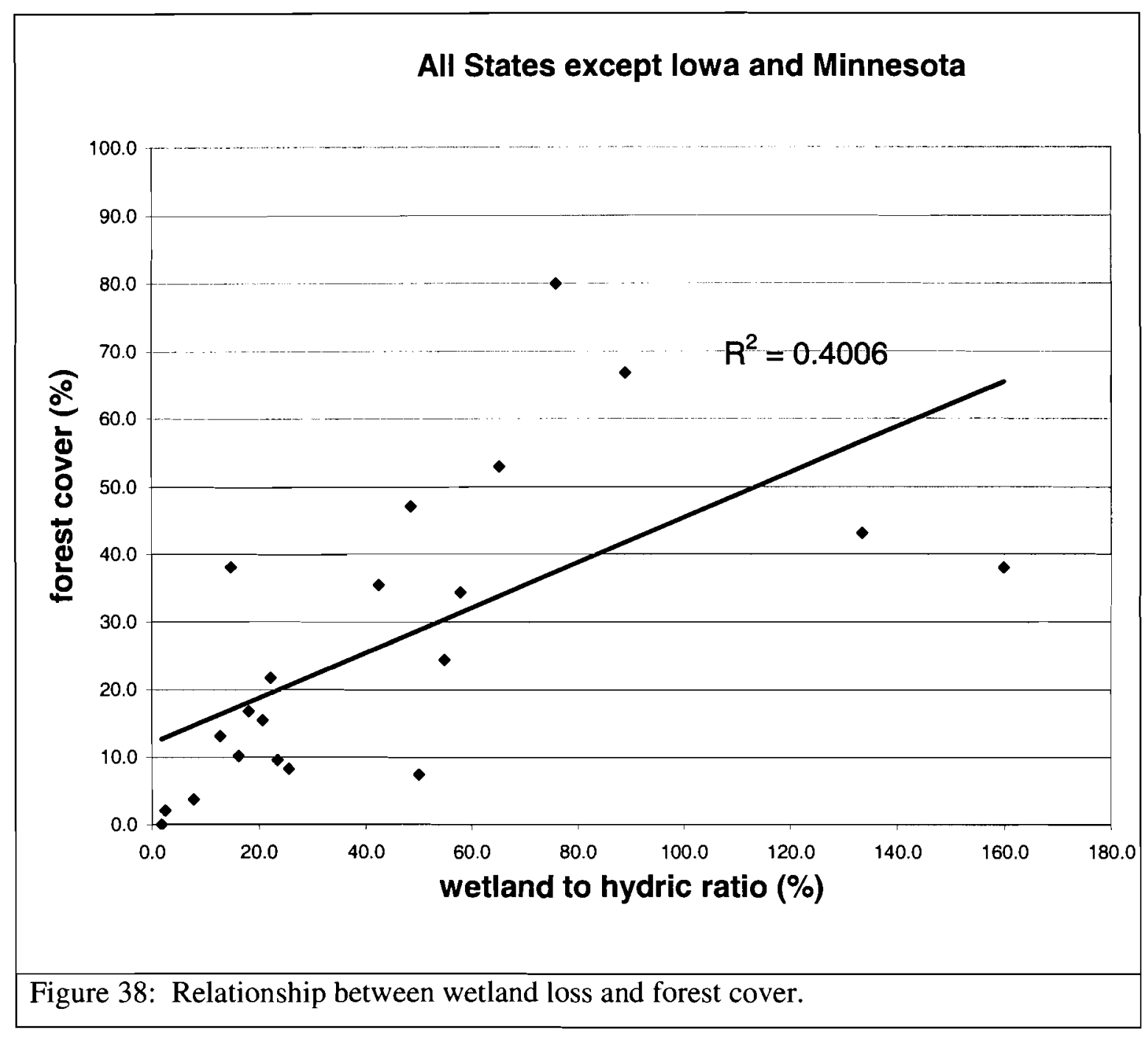

A trend can be seen here also, although once again not precisely linear. But as the forest cover, the natural state for most of these counties, increases the amount of potential historic wetlands remaining increases. Increased forest cover would indicate that the land has probably not been disturbed from its original state as much as a county where most of the forest cover has been removed. Minnesota and Iowa were left out of this data set due to these counties residing in predominantly prairie areas.

These two data sets indicate that a significant relationship exists between farming intensity and historic wetlands remaining and forest cover and historic wetlands remaining. Both are a measure of how much the land has been altered, though they approach the problem from different directions. However there are probably other factors at work. A couple of these could be urban sprawl and other road development, 
meaning county roads. County roads make up many more miles of roads than do state and federal roads in most counties.

One other factor was looked at in this project. Since part of the definition of a wetland is that it contains a hydric soil it was decided to see how well this played out with wetlands data versus hydric soil data. Using the Geoprocessing Wizard of ArcView an intersection of the wetlands shapefile and the hydric soils shapefile was performed on the counties analyzed. This intersection results in a shapefile with land areas common to both wetlands and hydric soils. If the definition of a wetland holds up then most of the wetlands should exist on hydric soils. Unfortunately this experiment produced mixed results as can be seen in the spreadsheet below.

\begin{tabular}{|c|c|c|c|c|c|c|c|c|c|c|}
\hline State & County & $\begin{array}{c}\text { area } \\
\text { (acres) }\end{array}$ & $\begin{array}{c}\text { county area } \\
\text { including lakes } \\
\text { (acres) }\end{array}$ & $\begin{array}{c}\text { hydric } \\
\text { (acres) }\end{array}$ & $\begin{array}{l}\text { wetlands } \\
\text { (acres) }\end{array}$ & $\begin{array}{c}\text { (wet/hydric) } \\
(\%)\end{array}$ & $\begin{array}{c}(\text { hyd/total }) \\
(\%)\end{array}$ & $\begin{array}{c}(\text { wet/total) } \\
(\%)\end{array}$ & $\begin{array}{c}\text { hydric } \\
\text { wetlands } \\
\text { intersection } \\
\text { (acres) }\end{array}$ & $\begin{array}{c}\text { wetlands } \\
\text { that are } \\
\text { hydric } \\
(\%)\end{array}$ \\
\hline \multirow{3}{*}{ Illinois } & Champaign & 638205 & 638,072 & 357219 & 6396 & 1.8 & 56.0 & 1.0 & 5543 & 86.7 \\
\hline & McHenry & 386654 & 390,947 & 108374 & 54266 & 50.1 & 27.7 & 13.9 & 49309 & 90.9 \\
\hline & Franklin & 179588 & 276,067 & 69517 & 38157 & 54.9 & 25.2 & 13.8 & 25713 & 67.4 \\
\hline lowa & Van Buren & 310561 & 313,760 & 83685 & 9031 & 10.8 & 26.7 & 2.9 & 5412 & 59.9 \\
\hline \multirow[t]{2}{*}{ Minnesota } & Sherburne & 279403 & 288,429 & 70594 & 60984 & 86.4 & 24.5 & 21.1 & 50511 & 82.8 \\
\hline & Wright & 422934 & 456,901 & 170574 & 141385 & 82.9 & 37.3 & 30.9 & 127709 & 90.3 \\
\hline Missouri & Wright & 436701 & 436,911 & 6496.5 & 2756 & 42.4 & 1.5 & 0.6 & 238 & 8.6 \\
\hline New Jersey & Hunterdon & 275261 & 279,940 & 17481 & 10100 & 57.8 & 6.2 & 3.6 & 6350 & 62.9 \\
\hline New York & St. Lawrence & 1718863 & $1,383,314$ & 292279 & 222107 & 76.0 & 21.1 & 16.1 & 105049 & 47.3 \\
\hline \multirow{10}{*}{ Indiana } & Elkhart & 296856 & 299,246 & 73055 & 17131 & 23.4 & 24.4 & 5.7 & 13964 & 81.5 \\
\hline & Carroll & 238251 & 239,849 & 67851 & 8626 & 12.7 & 28.3 & 3.6 & 4929 & 57.1 \\
\hline & Delaware & 251720 & 253,304 & 94217 & 7329 & 7.8 & 37.2 & 2.9 & 5014 & 68.4 \\
\hline & Fountain & 253264 & 254,465 & 57889 & 10474 & 18.1 & 22.7 & 4.1 & 3259 & 31.1 \\
\hline & Scott & 121856 & 123,284 & 57569 & 8514 & 14.8 & 46.7 & 6.9 & 4836 & 56.8 \\
\hline & Vermillion & 164418 & 166,232 & 30671 & 6793 & 22.1 & 18.5 & 4.1 & 2430 & 35.8 \\
\hline & Wayne & 258288 & 258,756 & 28866 & 7393 & 25.6 & 11.2 & 2.9 & 1482 & 20.0 \\
\hline & Perry & 244104 & 247,066 & 6184 & 5506 & 89.0 & 2.5 & 2.2 & 208 & 3.8 \\
\hline & Harrison & 310561 & 311,399 & 3023 & 4832 & 159.8 & 1.0 & 1.6 & 1205 & 24.9 \\
\hline & Owen & 246538 & 248,014 & 6306 & 8412 & 133.4 & 2.5 & 3.4 & 2555 & 30.4 \\
\hline
\end{tabular}

Several counties produced favorable results with percentages in the 70's, 80's, and 90's. However some were quite low. Tippecanoe County only produced a value of $44 \%$. It was thought that large rivers systems might be throwing off the data. An investigation was made for Tippecanoe county to see what would happen if a shapefile of all wetlands not touching a river or stream was created. This shapefile was then intersected with the hydric soil shapefile. This intersection however only produced a 
value of $58 \%$ of wetlands lying on hydric soils. While this was larger than $44 \%$ it was still low and indicated either a problem with the definition of a wetland or the data sets available from the government.

A suspicion of the accuracy of NWI wetlands data had occurred earlier. An excursion to southeastern Tippecanoe County to observe some of these wetlands in person produced surprising results. Several NWI wetlands did not appear to be wetlands at all, but rather forests. In addition several of these wetlands/forests had houses built in the middle of them. A conversation with one resident indicated that ponding of water was never a problem. Examination of the hydric soil maps for these wetlands showed that several of these areas did not contain hydric soils. The two figures below show the wetlands and hydric soils of this area. The two circled areas indicate two of the wetlands/forests that were observed. Note that hydric soils are not found in the same area in which the wetlands are found.

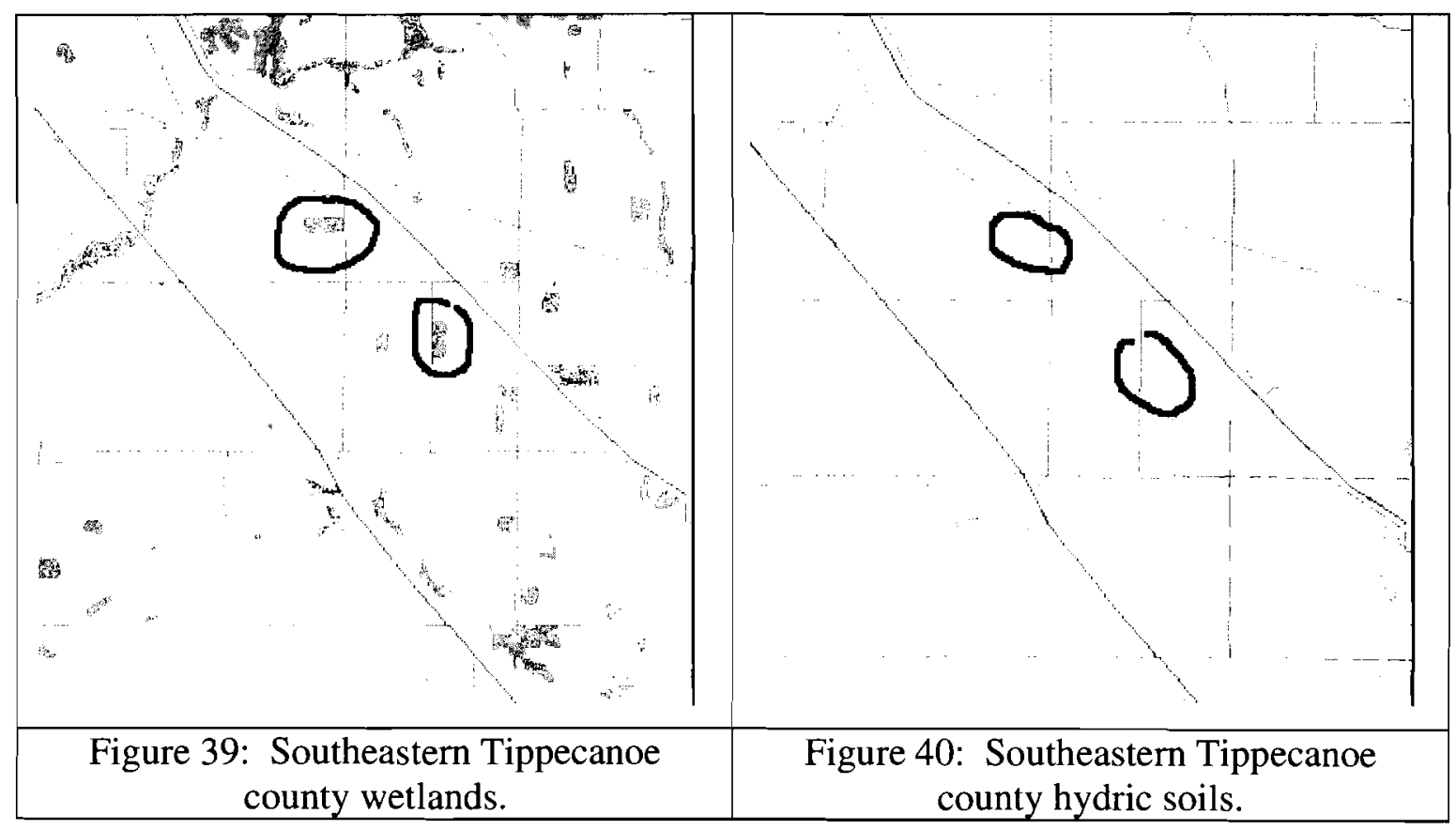

NWI wetland hardcopy maps are qualified with these and other words. "The aerial photographs typically reflect conditions during the specific year and season when they were taken. In addition, there is a margin of error inherent in the use of the aerial photographs (Santos)." There are other factors that could have affected the quality of the data such as poor quality photography or forest stands on a particular day could have had 
a very dark signature that would lead to it being mistaken for a wetland. Quality control steps, like limited field surveys and use of collateral data like soil surveys, are used to try to catch these problems. Also NWI data is derived from photos taken in the early to mid 80 's, so this data does not reflect any changes since that time (Santos). It should also be noted that while wetland delineation work by the U.S. Army Corps of Engineers requires all three definitions of a wetland; hydric soil, wetland hydrology, and hydrophytic vegetation, be present, NWI mapping requires only the wetland hydrology criteria always be met (Santos).

The result is that NWI wetland data requires only the wetland hydrology criteria be met, this project used only the hydric soil criteria for an estimation of historic wetlands, and for true delineation of wetlands all three criteria need to be met. Thus some error is going to creep into this process. Unfortunately there was not found any source, hard copy or digital, that has delineated and archived the wetlands of the U.S. or Indiana. Delineation, according to the U.S. Army Corps of Engineers, proceeds on a case by case basis. When an area of land is developed or transformed and wetlands may be affected, then a delineation needs to be carried out. But there has been no national effort to delineate wetlands nationwide. The NWI data comes closest and is a very useful tool, but is not a substitute for the delineation process. Local, state, and federal regulatory agencies still have jurisdiction over wetlands. 


\section{CONCLUSIONS and RECOMMENDATIONS}

The results obtained in this study demonstrated that while wetlands prevalence decreased slightly in land areas close to state and federal roads, this did not explain the dramatic decrease (in excess of $80 \%$ ) in wetlands that has occurred in Indiana. In fact, hydric soil prevalence (i.e., a common indicator parameter for wetland areas) decreased only to a slight extent in land areas close to federal and state roads.

Since soil data is not expected to change much over time, the latter fact (i.e., the nominal decrease in hydric soil lands immediately adjacent to highways) indicates that the slight decrease in wetlands near state and federal roads is not due to adverse effects by road construction itself. Instead this decrease may be due to roads being constructed in areas and paths intended to avoid wetlands and hydric soils, thus lowering construction time and costs.

While the data developed in this project does not clearly indicate whether state and federal road construction has had an obvious quantifiable negative impact on wetlands, this data does indicate that if there was an impact it was a very small impact in comparison to the dramatic decline in wetlands that has been estimated to have occurred within the state of Indiana. This decline could be due to many factors and research in this project has shown a correlation between wetlands loss as represented by the wetlands to hydric soil ratio and farming intensity and an opposite correlation between wetland loss and forest cover. The greater the farming intensity within a county the greater the estimated loss of wetlands. Also the greater the area of forest cover within a county correlated with a lower estimated wetland loss.

This is an area in which more research could be performed. Two other factors that have not been examined in this project are the effect of county roads upon wetlands and the effect of urban sprawl upon wetlands. These are two factors that may have played significant roles in wetlands destruction. A problem lies in separating the effects on wetlands of agriculture, urban sprawl, state and federal roads, and county roads from each other. All of these developments have occurred simultaneously and often overlap each other spatially. 
The lack of a consistently strong correlation of wetlands lying on hydric soils is troubling. The foundation for this project is the part of the definition of a wetland that requires it to be characterized by hydric soils. That was the only way found to gauge an estimate of historic wetlands. The discrepency between the wetlands definition and the fact that many NWI wetlands, which are based upon the wetland hydrology part of the wetland definition, do not lie within SSURGO hydric soils introduces a certain amount of error in this process. However NWI data is the best wetlands data available and the USDA SSURGO soils data is the best soils data available.

A final note of importance is that this project is entirely based upon quantifiable data. Qualitative evaluations of state and federal road development effects upon wetlands is not the focus of this research, but has been touched upon in the research of others. Such research has sought to determine the effects of human land development and road construction on wetlands with the effect being a loss of biodiversity. A decline in biodiversity results from road construction due to wetland fragmentation, restricted movement between wetlands and species populations, roadkill, and increased human access to these ecosystems. Research has shown that much of this effect is not immediate but takes place over many years after the initial disrupting event (Findlay and Bourdages). The negative effects land development, human populations, and urban sprawl have on the biodiversity of wetlands is the result of wetland fragmentation. Minimum wetland densities are required to sustain healthy populations in these ecosystems. Even though these wetlands are not continuous systems, they are interdependent systems because their proximities to one another affect the ability of populations to genetically mix (Gibbs). 


\section{RECOMMENDATIONS}

Based on the findings developed during this research effort, the following recommendations are proposed for future investigation of this topic:

1) Examine the effect of county roads upon wetlands using the procedures developed and documented with this project, and

2) Examine the effect of urban sprawl on wetlands, in relation to historical highway routing and construction. 


\section{REFERENCES}

Findlay, C. S. and Bourdages, J. (2000). "Response Time of Wetland Biodiversity to Road Construction on Adjacent Lands." Conservation Biology. Vol 14 Feb 2000, pp. 86-91.

Franzmeier, D. P. and Kladivko, E. J. (2000). Personal Communication, Department of Agronomy, Purdue University, West Lafayette, Indiana.

Findlay, C. S. and Bourdages, J. (2000). "Response Time of Wetland Biodiversity to Road Construction on Adjacent Lands." Conservation Biology. Vol 14 Feb 2000, pp. 86-91.

Gibbs, James P. (2000). "Wetland Loss and Biodiversity Conservation." Conservation Biology v 14 Feb 2000, pp. 314-317.

Harbor, J. (2001). Personal Communication. Department of Earth and Atmospheric Sciences, Purdue University, West Lafayette, Indiana.

Miller, B. K. and MacGowan, B. J. (2001). Personal Communication. Department of Forestry and Natural Resources, Purdue University Cooperative Extension Service, West Lafayette, Indiana.

NRCS at a Glance. http://www.nrcs.usda.gov/NRCSglnc.html

NRCS Distribution of Wetlands. http://www.nhq.nrcs.usda.gov/land/meta/m2702.html

NRCS SSURGO Data Users Guide (via PDF file format)

http://www.ftw.nrcs.usda.gov/ssur data.html

NWI homepage. http://www.nwi.fws.gov/

NWI Overview. http://www.nwi.fws.gov/overiew.htm

U.S. Army Corps of Engineers Wetlands Delineation Manual. Wetlands Research Program Technical Report Y-87-1. http://www.wes.army.mil/el/wetlands/wetlands.html

U.S. Map of SSURGO Digitized County Soil Data.

http://www.ftw.nrcs.usda.gov/jpg/archived.jpg

U.S. Map of Digitized NWI Wetlands Data. http://wetlands.fws.gov/images/webstat.gif

Santos, K. (2000). Personal Communication. Regional Wetlands Coordinator for Region 3 (Midwest_Region), U.S. Fish and Wildlife Service. 